\title{
Molecular and cellular mediators of Alzheimer's disease inflammation
}

\author{
Ron Strohmeyer and Joseph Rogers* \\ Sun Health Research Institute, 10515 West Santa Fe \\ Drive, Sun City, AZ 85351, USA
}

\section{Introduction}

A wide range of inflammatory mediators has been demonstrated in the Alzheimer's disease (AD) brain during the past 15 years (for previous reviews, see [6, 279,298,340,343]). Questions nonetheless remain, including even the designation of AD inflammatory mechanisms as a true inflammatory response. Like multiple sclerosis, the cardinal signs of peripheral inflammation, the "rubor et tumor cum calore et dolore" (redness and swelling with heat and pain) that Cornelius Celsus defined as criteria 2000 years ago, are not present in $\mathrm{AD}$. Indeed, AD inflammation does not appear to include even cell-mediated humoral lymphocyte responses, as multiple sclerosis clearly does. Rather, our current understanding of $\mathrm{AD}$ inflammation suggests that it is an endogenously-mediated, localized reaction, an innate inflammatory response similar to that mounted in the periphery when localized tissue damage and the chronic deposition of highly insoluble, abnormal material occurs. Such primarily macrophagemediated reactions have been classed as inflammatory for over a century, and that designation, with glia as the brain intermediaries, certainly should hold for AD.

Henry Wisniewski, who we honor by this special journal issue, was one of the first to come to grips with these simple principles of $\mathrm{AD}$ inflammation, and to apply them to other brain disorders. If we understand that localized brain inflammation is likely to arise wherever there is localized brain damage and deposits of highly insoluble, abnormal material, then prion diseases be-

\footnotetext{
* Correspondence: Dr. Joseph Rogers, Sun Health Research Institute, P.O. Box 1278, Sun City, AZ 85372, USA. Tel.: +1 623876 5328; Fax: +1 623876 5461; E-mail: jrogers@mail.sunhealth.org.
}

come an obvious research target. Wisniewski and his colleagues therefore looked for and found numerous indices of localized inflammation in prion-infected brain [195,214], just as McGeer and colleagues had done in dopamine-degenerating areas of the Parkinson's disease brain [274]. In fact, among his many studies of multiple sclerosis and experimental allergic encephalitis, Wisniewski pointed out that primary demyelination could be induced as a nonspecific consequence of cell-mediated inflammatory actions in the absence of autoantibodies to myelin [443]. This observation, published in 1975, presaged much of what we now believe about localized inflammatory actions in the AD brain.

A simplified view of $\mathrm{AD}$ inflammation also leads to clearer understanding of the roots and roles that inflammatory mechanisms may play in AD. As a localized response to tissue injury and the chronic presence of abnormal, highly insoluble deposits, AD inflammation is unlikely to be an AD etiology, although new data on cytokine susceptibility polymorphisms [88,319] suggest that it could in certain cases be a risk factor. That it is a secondary response, however, does not mean that $\mathrm{AD}$ inflammation is unimportant. In brain injury due to head trauma, for example, the etiology, the blow to the head, may cause less damage than the secondary inflammatory response to it. Although eliminating the head trauma is obviously the most satisfactory way to handle the problem, once it has occurred it becomes important to control the inflammatory reaction. Similarly, until we can eliminate the primary insult that causes $\mathrm{AD}$ neurodegeneration and the deposition of amyloid $\beta$ peptide (A $\beta$ ) and neurofibrillary tangles, abrogating the initiation of secondary inflammatory damage will continue to be an important therapeutic target. Toward that end, we attempt here to summarize the evidence for a pathophysiologically relevant role of $\mathrm{AD}$ inflammation, and to catalogue the many inflammatory mediators present in affected areas of the AD brain. 


\section{Cell mediators of inflammation in the AD brain}

Although the new data on a vaccination approach to removing $\mathrm{A} \beta$ by antibody-antigen mechanisms [355] may yet bring surprises, to date there has been no conclusive evidence that antibodies or peripheral leukocytes are normally involved in AD inflammation. Rather, microglia and astrocytes appear capable of producing nearly every pro-inflammatory component observed thus far in the AD brain (Table 1). Surprisingly, accumulating evidence indicates that neurons also supplement the glial repertoire of pro-inflammatory factors, and oligodendrocytes and vascular endothelial cells may contribute as well. For convenience, these data are summarized in the accompanying table (Table 1).

\subsection{Astrocytes}

Astrocytes are immunologically activated by various challenges and respond to inflammatory mediators in pleiotropic fashion, including activation of early response genes and expression of various adhesion proteins, cytokines, eicosanoids, proteases, and other cytotoxic molecules in vitro and in situ (Table 1) [93]. In addition to overt inflammatory actions, ectoenzymes secreted by AD astrocytes may also play a role in degrading plaque $\mathrm{A} \beta$ [439], removing capillaries with amyloid angiopathy [445], and degrading paired helical filaments (PHF) [334,460].

Activated astrocytes are transformed into "reactive astrocytes" manifesting upregulated glial fibrillary acidic protein (GFAP) expression, astrocytic swelling, hypertrophy, hyperplasia, and gliosis [251,285]. In the AD brain focal and diffuse astrocytosis develops [85, 90,149,252,253,334,354,360,460] and advanced AD may include a nearly four-fold increase in astrocyte numbers [354]. The astrocytes appear around ghost tangles, dark neurons, capillaries ravaged by $\mathrm{A} \beta$, areas of ischemic damage, and $\mathrm{A} \beta$ plaques. Astrocytes exhibit distinct morphological characteristics in each of these pathological interactions, possibly indicating a distinct role in each. Astrocytic accrual in plaques appears to be a reaction to focal extracellular $\mathrm{A} \beta$ accumulation $[85,253,254,444,445]$ and, with fibrillar A $\beta$ plaque development, is limited to the cerebral cortex and subcortical gray matter. Although a few reactive astrocytes are present in virtually all diffuse (noncongophillic) plaques, their greatest densities occur in neuritic plaques. Astrocytes are seldom associated with dense core, non-neuritic ("burned out”) plaques [290].
The position of astrocytes in plaques differs from that of microglia. Astrocyte somas form a corona at the periphery of the neuritic halo that, in turn, may surround a dense core $\mathrm{A} \beta$ deposit. Processes from the astrocytes cover and interdigitate the neurite layer [290] in a manner reminiscent of glial scarring, and there is, in fact, recent evidence that plaque-associated astrocytes may be creating barriers: microglial clearance of deposited $\mathrm{A} \beta$ in culture is less efficient when astrocytes are plated before the microglia than when microglia alone are used [84,361]. This may be due to the fact that astrocytes deposit proteoglycans that inhibit the ability of microglia to clear plaques [84,361], consistent with the conspicuous localization of proteoglycans to plaques [376].

\subsection{Microglia}

Microglial cells constitute approximately 10-15\% of the cellular population in the brain $[31,62,278]$. It is generally accepted that microglia have a monocytic origin $[31,325,326]$ and by that derivation possess an inherent macrophage-like phagocytic capacity [134, 206]. Microglial cells typically assume a resting (unactivated) state, having a ramified appearance, expressing virtually no macrophage-like characteristics, and exhibiting a very low turnover [31,205,212]. Activation of microglia causes them to assume an amoeboid morphology, to become phagocytic, and to express MHC II and numerous other macrophage-like pro-inflammatory molecules (reviewed in $[31,134,206$, 307,427]).

Although in the normal brain microglia play neurotrophic roles (reviewed in [31,386]), their potential neurotoxic actions have been emphasized in AD research. By numerous criteria microglia in the AD brain, like microglia in a variety of neuropathologic conditions [129,288,289,385,386], are appropriately considered to be activated [31]. These criteria include altered morphology and increased expression of MHC II, cytokines, chemokines, complement, other acute phase proteins, and potential neurotoxins (Table 1), all of which could contribute to localized or more widespread CNS injury [31,307]. In some cases (e.g., complement) microglial production of these mediators in the AD brain has been inferred from studies of isolated culture preparations, where expression can be unequivocally attributed to a particular cell type. Limitations of in situ hybridization - where the hybridization label is not precisely localized due to scattering of the radioactive signal and where the substantially greater mass of 
Table 1 , continued

\begin{tabular}{|c|c|c|c|c|}
\hline Marker & $\Delta$ in $\mathrm{AD}$ & Pathology & Cell & Method \\
\hline \multirow[t]{2}{*}{ Nitrotyrosine (and derivatives) } & $\uparrow$ & NFTs $[140]$ & & HPLC \\
\hline & $\uparrow$ & Hippocampus, cortical regions, and CSF [152] & & \\
\hline \multirow{7}{*}{$\begin{array}{l}\text { Peroxynitrite } \\
\text { nitrotyrosine-modified proteins } \\
\text { p22-phox (NADPH subunit) } \\
\text { MPO (myeloperoxidase) } \\
\text { Iron ( } \mathrm{Fe} \text { ) }\end{array}$} & $\uparrow$ & Neurons and NFT bearing neurons $[374,391]$ & $\mathrm{N}$ & \\
\hline & $\uparrow$ & {$[140,152,374,391]$} & & \\
\hline & $\uparrow$ & [415] & & IHC \\
\hline & $\uparrow$ & Plaques and associated microglia [337] & M & \\
\hline & $\uparrow$ & Multiple brain regions $[94,352,405]$ & & \\
\hline & $\uparrow$ & NFTs neurons vs non-NFT neurons in AD [139] & $\mathrm{N}$ & \\
\hline & $\uparrow$ & Plaques and associated microglia [145] & M & \\
\hline \multirow[t]{2}{*}{ Ferritin } & $\uparrow$ & Plaque associated microglia [145] & M & \\
\hline & $\uparrow$ & Ferritin has more $\mathrm{Fe}$ in $\mathrm{AD}[117]$ & & \\
\hline \multirow{3}{*}{$\begin{array}{l}\text { Melanotransferin } \\
\text { Lipid peroxidation } \\
\text { iNOS }\end{array}$} & $\uparrow$ & Serum, CSF, plaque associated microglia $[178,193]$ & M & \\
\hline & $\uparrow$ & Multiple brain regions $[28,235,317,392]$ & & $\mathrm{IHC}$ \\
\hline & $\uparrow$ & Hirano bodies, plaques, NFTs [216] & $\mathrm{N}$ & \\
\hline \multirow{4}{*}{$\begin{array}{l}\text { Transcription Factors } \\
\text { NF- } \kappa \mathrm{B}(\mathrm{p} 65)\end{array}$} & & & & EMSA \\
\hline & $\uparrow$ & Parallel increase with COX-2 mRNA [245] & & $\mathrm{IHC}$ \\
\hline & $\uparrow$ & $\begin{array}{l}\text { Hippocampus, entorhinal, temporal, and visual } \\
\text { cortex neurons }[110,187,199,401]\end{array}$ & $\mathrm{N}$ & $\mathrm{IHC}$ \\
\hline & $\uparrow$ & Nucleus Basalis cholinergic neurons [44] & $\mathrm{N}$ & WB \\
\hline \multirow{7}{*}{$\begin{array}{l}\text { PPAR- } \gamma \\
\text { pCREB } \\
\text { ATF } \\
\text { c-fos }\end{array}$} & $\uparrow$ & Temporal cortex [198] & & WB \\
\hline & $\downarrow$ & Phosphorylated CREB in hippocampus [461] & & $\mathrm{IHC}$ \\
\hline & $\uparrow$ & Cortical neurons [458] & $\mathrm{N}$ & ISH \\
\hline & $\uparrow$ & Hippocampus neurons [239] & $\mathrm{N}$ & IHC \\
\hline & $\uparrow$ & Hippocampus neurons [255] & $\mathrm{N}$ & $\mathrm{IHC}$ \\
\hline & $\uparrow$ & Cortical and plaque associated astrocytes [22] & A & $\mathrm{IHC}$ \\
\hline & $\uparrow$ & PHF-1 expressing neurons [22] & $\mathrm{N}$ & $\mathrm{IHC}$ \\
\hline \multirow[t]{4}{*}{ c-jun } & $\uparrow$ & Hippocampus neurons $[247,255]$ & $\mathrm{N}$ & IHC \\
\hline & $\uparrow$ & Cortical and plaque associated astrocytes $[22,111]$ & A & $\mathrm{IHC}$ \\
\hline & $\uparrow$ & PHF-1 expressing neurons [22] & $\mathrm{N}$ & IHC \\
\hline & $\uparrow$ & Meningeal and cerebral vessels with CAA [111] & & ISH \\
\hline Krox24 & $\uparrow$ & Hippocampus neurons [247] & $\mathrm{N}$ & WB \\
\hline STAT1 & $\uparrow$ & Temporal cortex [199] & & \\
\hline \multicolumn{5}{|l|}{ Miscellaneous Receptors } \\
\hline A $\beta$-binding Receptors & $\uparrow$ & Upregulated on neurons and microglia $[464,466]$ & $\mathrm{N}, \mathrm{M}$ & $\mathrm{IHC}$ \\
\hline \multirow{2}{*}{$\begin{array}{l}\text { RAGE } \\
\text { MSR (macrophage } \quad \text { scavenger } \\
\text { receptor) }\end{array}$} & $\uparrow$ & Expressed on AD microglia $[66,100,101,161]$ & M & $\mathrm{IHC}$ \\
\hline & $\uparrow$ & Plaques [66], (review [371]) & & \\
\hline FPR (fMLP receptor) & $\uparrow$ & $\begin{array}{l}\text { Chemotactic for } \mathrm{A} \beta[234] \text { (expressed on } \mathrm{AD} \\
\text { microglia - D. Lorton personal communication) }\end{array}$ & M & IHC \\
\hline \multicolumn{5}{|l|}{ Other Receptors } \\
\hline $\mathrm{Fc} \gamma \mathrm{R} 1$ & $\uparrow$ & Activated microglia $[11,274]$ & M & $\mathrm{IHC}$ \\
\hline $\mathrm{Fc} \gamma \mathrm{R} 2$ & $\uparrow$ & Activated microglia [274] & $\mathrm{M}$ & $\mathrm{IHC}$ \\
\hline \multicolumn{5}{|c|}{$\begin{array}{l}\text { This table represents those factors that have been specifically detected in the AD brain and its related pathologies to date. It should } \\
\text { be noted that many more inflammatory factors and related proteins have been observed in cell culture and animal models. Thus, } \\
\text { this list, without a doubt, will continue to grow. Abbreviations: WB, western blot; IHC, immunohistochemistry; ISH, in situ } \\
\text { hybridization; ELISA or EIA, enzyme linked immunosorbent assay; PCR, (reverse transcriptase) polymerase chain reaction; EM, } \\
\text { electron microscopy; RIA, radio immunoassay; BA, bioassay; NB, northern blot; GC/MS, gas chromatography/mass spectroscopy; } \\
\text { HPLC, high pressure liquid chromatography; EMSA, electrophoretic mobility shift assay; N, neuron; A, astrocyte; M, microglia; } \\
\text { E, endothelia; O, oligodendroglia; NFTs, neurofibrillary tangles; ND, nondemented; AD, Alzheimer's disease; CSF, cerebral spinal } \\
\text { fluid; MAC, membrane attack complex; } \uparrow \text {, increased in AD compared to ND; } \downarrow \text {, decreased in AD compared to ND; } \leftrightarrow \text {, no difference } \\
\text { between AD and ND; NC, not compared. }\end{array}$} \\
\hline
\end{tabular}

labelled neurons can easily obscure labelling of relatively tiny microglia - have sometimes made it difficult to confirm the culture observations. However, the fact that activated macrophages, close cousins to microglia, are known to express inflammatory mediators such as complement lends confidence to the conclusions from culture studies that microglia do so as well.
As do astrocytes, activated microglia cluster at sites of aggregated $\mathrm{A} \beta$ deposition. However, microglia assume a more central position and deeply interdigitate plaques in contrast to the peripheral position of astrocytes. Like astrocytes, microglia are present in virtually all diffuse (noncongophilic) plaques, but the greatest densities of microglia are in neuritic plaques. They 
are seldom associated with dense core, non-neuritic ("burned out") plaques [142,144]. This co-localization of microglia and astrocytes with $\mathrm{A} \beta$ deposits provides opportunities for intercellular inflammatory signaling. IL-1 $\beta$ secreted by microglia, for example, induces astrocyte expression of $\mathrm{S} 100 \beta$ protein [367].

The clustering of microglia within plaques is readily explained by chemotactic signaling by $\mathrm{A} \beta$ itself [79] and by several inflammatory mediators that are associated with $\mathrm{A} \beta$ in senile plaques, including complement activation fragments, cytokines, and chemokines (reviewed in [307]). In addition, AD microglia reportedly upregulate their expression of the macrophage scavenger receptor (MSR) [100] and the receptor for advanced glycation end products (RAGE) [464], both of which appear to have $\mathrm{A} \beta$ as ligands [100,464]. Stimulation of the RAGE receptor with $\mathrm{A} \beta$ induces $\mathrm{M}$ CSF [466] in microglia just as it does in macrophages. Similarly, adhesion of microglia to $\mathrm{A} \beta$ fibrils via class A scavenger receptors leads to immobilization of the cells and induces production of reactive oxygen species $[100,101]$. It has also recently been demonstrated that the chemotactic formyl peptide receptor (FPR) binds $\mathrm{A} \beta$, triggering $\mathrm{G}$ protein dependent calcium mobilization and activation of chemokine signal transduction pathways [234].

$\mathrm{A} \beta$ activates numerous signaling cascades within microglia $[67,250,271]$ that are common to peripheral inflammatory responses. Among these are the tyrosine kinase-based cascades [270,450], calcium-dependent activation of Pyk 2 and PKC pathways [67], and p38 and ERKs MAP kinase cascades [67,270]. These, and certainly others, lead to the activation of transcription factors responsible for subsequent pro-inflammatory gene expression. Furthermore, $\mathrm{A} \beta$-stimulated activation of intracellular signaling pathways in microglia leads to production of reactive oxygen species through NADPH oxidase, and to the synthesis and secretion of neurotoxins $[68,83,271]$ and excitotoxins. Excitotoxins released by activated microglia - for example, glutamate [329] and quinolinic acid [104] - can cause significant dendritic pruning as these molecules act preferentially on vulnerable subcellular synaptic and dendritic compartments [265]. Notably, synapse loss is one of the most consistent correlates of AD cognitive impairment [261, 403].

Beyond their chemotaxis and physical proximity to $\mathrm{A} \beta$ deposits, the role of microglia in plaque evolution is still incompletely understood. Several hypotheses have been put forward involving synthesis, processing, and catabolism of $\mathrm{A} \beta$ by microglia. Of least probability is that microglia play a direct role in the synthesis of amyloid $\beta$ protein precursor $(\mathrm{A} \beta \mathrm{PP})$ and deposition of $\mathrm{A} \beta$. Although cultured microglia can secrete $\mathrm{A} \beta$ and metabolize $\mathrm{A} \beta \mathrm{PP}$ in a manner that might favor $\mathrm{A} \beta$ deposition [32,39], microglial $\mathrm{A} \beta \mathrm{PP}$ mRNA expression is yet to be demonstrated [358]. Conversely, neurons in vivo and neurons in culture exhibit abundant expression of $\mathrm{A} \beta \mathrm{PP}[213]$ and are postulated to be the primary source of brain $\mathrm{A} \beta$.

A potential role for microglia in processing $\mathrm{A} \beta \mathrm{PP}$ and $A \beta$ is more tenable. Microglial aggregation within amyloid-containing neuritic plaques is nearly universal, whereas it is rare or absent in diffuse plaques in $\mathrm{AD}$, normal aging $[74,174,249,348]$, or $\mathrm{A} \beta \mathrm{PP}$ transgenic mice $[120,381]$. This association suggests that microglia, like peripheral macrophages in systemic amyloidosis [370], may be involved in the conversion of nonfibrillar A $\beta$ into amyloid fibrils. Such a possibility is supported by many studies [76,141,248,353,427], including ultrastructural observations consistent with the possibility that microglia may participate in the laying down of amyloid fibrils within plaques [445].

Finally, catabolism by microglia via phagocytosis and/or degrading of $\mathrm{A} \beta$ deposits is another plausible prospect, in keeping with the emerging view that amyloid burden in the AD brain is determined by a dynamic balance between amyloid deposition and removal [168]. Many laboratories have shown that microglia actively phagocytose exogenous fibrillar $\mathrm{A} \beta$ in vivo and in culture [26,84,119,241,315,320,361,362, 369]. Although cultured AD microglia phagocytose $\mathrm{A} \beta$ [241], it is presently unknown if they degrade it or secrete it in some other form. That they remove $\mathrm{A} \beta$ deposits, however, is strongly supported by the recent demonstration of $\mathrm{A} \beta$ co-localized with a microglial activation marker, $\mathrm{MHC}$ II, in $\mathrm{A} \beta$-immunized PDAPP transgenic mice, where amyloid deposits were apparently cleared [355]. Phagocytosis in these mice likely occurs via the variety of $\mathrm{A} \beta$ binding receptors and by opsoninization for complement clearance. Interestingly, however, the first classical pathway complement component, $\mathrm{C} 1 \mathrm{q}$, binds to $\mathrm{A} \beta[5,63,180,433,435]$, and has been suggested to block critical $\mathrm{A} \beta$ epitopes for $\mathrm{A} \beta$ uptake by cultured microglia [438].

Although, phagocytosis of $\mathrm{A} \beta$ has generally been considered beneficial, $\mathrm{A} \beta$ association with microglia, as previously described, results in extensive activation of signal transduction pathways leading to the formation of numerous pro-inflammatory, neurotoxic, and excitotoxic molecules. Thus, there is also evidence that this process may encourage microglial activation to a neurocytopathic state $[3,61,81,86,203,297,411]$. 


\subsection{Neurons}

In addition to astrocytes and microglia, neurons themselves may exacerbate inflammatory reactions in their vicinity and so contribute to their own destruction in AD. For example, neurons appear capable of producing inflammatory mediators. These include complement $[115,323,363,402]$, cyclooxygenase (COX) [155,303,309,314,407,459], pro-inflammatory cytokines [48,51,138,301,316,394,399,465], the IL-6 receptor signal transducing component gp130 [169], M-CSF [466], and others (Table 1). Virtually all of these mediators are increased in the AD brain and have classical pro-inflammatory roles that could foment neurodegeneration.

\section{Inflammatory constituents in the AD brain}

\subsection{Complement pathways, activation products, defense proteins, receptors}

The complement pathways (classical and alternative) are composed of more than 30 proteins, many of them serine proteases that can be sequentially activated as an amplifying cascade. Both pathways converge at the $\mathrm{C} 3$ cleavage step and terminate in the pore-forming $\mathrm{C} 5 \mathrm{~b} 9$ membrane attack complex (MAC) (reviewed in [207, 296,318,441]). The transmembrane channel caused by MAC assembly at the cell surface permits the free diffusion of ions and small molecules into and out of the cell, disrupting cellular homeostasis, especially $\mathrm{Ca}^{++}$ homeostasis, and ultimately resulting in cell lysis if a sufficient number of MAC complexes have assembled on the cell. Notably, the MAC can also cause bystander lysis of healthy adjacent tissue [207,296,318,441]. In order to hold the complement cascades in check under normal circumstances, thereby protecting the host from self-lysis of healthy cells, and in order to down-regulate activated cascades during an immune response once the stimulus is depleted [207], tight regulation by a number of regulatory proteins is required [296,318,441]. Virtually all the proteins and respective mRNAs for the classical pathway, most of the alternative pathway, and the majority of complement regulatory proteins have been detected in the brain [115,182,363,388,430,470] and nearly all are up-regulated in $\mathrm{AD}$ (reviewed in [307, $341,343,470])$.

At the cellular level, three endogenous sources for complement have been suggested. Microglia [146,243, $420,426,428]$ and astrocytes [123-125,220,429] in situ and in culture appear to synthesize nearly all complement proteins. Remarkably, however, in situ hybridization studies suggest that neurons exhibit more abundant signal for complement mRNAs than any other cell type in the AD brain and express virtually all the proteins of the complement pathways [115,182,208,363,402]. Indeed, based on hybridization results, one study has suggested that complement production in the AD brain may be as great as that in the liver, the primary source of complement in the periphery [470]. Thus, multiple endogenous sources of complement exist in the brain, and at least two of these, neurons and microglia, show complement upregulation in $\mathrm{AD}$.

$\beta$-pleated, fibrillar $\mathrm{A} \beta[4,63,180,339,433,435]$ and, more recently, tau-containing neurofibrillary tangles [342] have been shown to directly activate the classical complement pathway fully in vitro, and to do so in the absence of antibody. $\mathrm{A} \beta$ activates the classical pathway via charge-based binding between $\mathrm{A} \beta$ and the collagen-like region of the C1q A chain [130,180,434]. Additionally, the hexameric structure of $\mathrm{C} 1 \mathrm{q}$ appears to facilitate further aggregation of $\mathrm{A} \beta$ by binding multiple A $\beta$ molecules $[434,436,437]$. Direct, antibodyindependent activation of the alternative pathway by $\beta$-pleated fibrillar $\mathrm{A} \beta$ has also been demonstrated [50, 388,432]. For the classical and alternative pathway, activation appears to proceed via covalent ester-linked complexes of $\mathrm{A} \beta$ with $\mathrm{C} 3$ [50], as is characteristic of complement activation reactions.

In addition to $\mathrm{A} \beta$ aggregates and neurofibrillary tangles, other potential sources for classical pathway activation exist in the AD brain. Neurodegeneration can ultimately expose DNA and neurofilaments to the extracellular environment. DNA [130] and neurofilaments [228] appear to interact with the $\mathrm{Clq} A$ chain similar to other antibody-independent activators of complement [130,181]. In addition, oligodendrocyte myelin glycoprotein activates the complement pathway in vitro [181], as do other myelin derived proteins (reviewed in [379]). It is therefore possible that the increased availability of complement in the AD brain might ultimately impact myelinated axons, perhaps helping to account for $\mathrm{AD}$ white matter changes that have recently been noted [400].

In summary, $\mathrm{A} \beta$ and neurofibrillary tangles, which represent highly insoluble deposits of abnormal proteins, and the exposed cellular byproducts of degeneration, including neurofilaments, naked DNA, and myelin fragments, appear to potently activate complement. This profuse and chronic presence in the AD cortex of multiple complement activating sources, to- 
gether with a highly competent endogenous source for complement production, makes it difficult to imagine that a chronic state of complement activation would not occur in the AD brain.

\subsection{Cytokines and chemokines and related receptors}

Cytokines and chemokines presumably subserve similar intercellular and intracellular signaling processes in microglia and astrocytes as they do in the periphery, although novel cytokine and chemokine mechanisms have been proposed in the CNS. Virtually all the cytokines and chemokines that have been studied in $\mathrm{AD}$, especially the major pro-inflammatory mediators, IL-1, IL-6, TNF $\alpha$, IL-8, transforming growth factor$\beta$ (TGF- $\beta$ ), and macrophage inflammatory protein- $1 \alpha$ (MIP-1 $\alpha$ ), are upregulated in AD compared to ND samples (Table 1) (reviewed in [307,453]).

Both cytokines and chemokines appear to pleiotropically activate numerous inflammatory response genes in $\mathrm{AD}$ and most of these proteins are expressed by astrocytes, microglia, and in some cases, neurons. $\mathrm{A} \beta$ appears to be capable of inducing the expression of cytokines and chemokines in these cells, and cytokines and chemokines are often detected in $\mathrm{A} \beta$ plaques. Concomitantly, exaggerated cytokine levels appear to induce increased expression of $\mathrm{A} \beta \mathrm{PP}$ and $\mathrm{A} \beta$.

Cytokine and chemokine expression has been reported to wax and wane with plaque evolution, with highest expression occurring in early diffuse and densecore neuritic plaques. Many of these factors seem to have dystrophic effects on neurites within and neurons around $\mathrm{A} \beta$ plaques, and may thereby play functional roles in plaque evolution. Conversely, paradoxical neuroprotective roles have been suggested for a few of the pro-inflammatory cytokines. These findings have most often resulted from assays of isolated neuron cultures or knockout preparations, and require confirmation under conditions that permit cytokine interactions with other cell types (e.g., glia) and systems (e.g., the vasculature) (reviewed in [307]). Transgenic mice that over express pro-inflammatory cytokines under the control of brain-specific promoters consistently exhibit inflammatory pathology, with little or no evidence of neuroprotection [19,52,153,380].

Two major pathophysiologic consequences of cytokine and chemokine upregulation in the AD brain have been proposed. First, there is the potential for vicious cycles in which cytokines induce $\mathrm{A} \beta$ and $\mathrm{A} \beta$ induces cytokines. Second, autocrine-paracrine cytokine and chemokine interactions among cells pro- ducing cytokines and chemokines are likely to occur, with net effects on cellular responses that can be additive, synergistic, inhibitory, or antagonistic [330]. Interactions among pro-inflammatory cytokines and chemokines, for example, can result in synergistic activities in cytokine production and actions, including effects on $\mathrm{A} \beta$ secretion. Low levels of antagonistic anti-inflammatory cytokines and receptors may further compound chronic inflammation. Such a dysregulation in the balance between pro-inflammatory and antiinflammatory mediators could lead to a deleterious amplification cycle of cellular activation and cytotoxicity [331]. Thus, both cytokine-cytokine interactions and cytokine interactions with existing AD pathology may play critical roles in AD neuroinflammation.

\subsection{Cyclooxygenase}

Cyclooxygenase (COX) is an enzyme that plays a pivotal role in the arachidonate cascade leading to prostaglandin synthesis. COX helps to mediate production of prostaglandins and other inflammatory factors and is itself upregulated by some of the same proinflammatory mediators it induces [106,313,351,462]. Recently, two isoforms of COX, COX-1 and COX-2, have been identified in the periphery and the brain (reviewed in [311]). Many cell types constitutively express COX-1, and the prostaglandins it helps produce are not all pro-inflammatory. In contrast, COX-2 is typically not constitutively expressed but is induced at sites of inflammation, facilitating the induction of proinflammatory prostaglandins. Because prostaglandins are so deeply entwined with other inflammatory mechanisms, the inhibition of COX, with its attendant inhibition of prostaglandins, has become a popular therapeutic target in AD.

Accumulating evidence indicates that COX-2 protein levels are increased in several areas of the $\mathrm{AD}$ brain and may correlate with levels of $\mathrm{A} \beta$ and plaque density $[155,198,322]$. As well, there is one report of COX-2 protein colocalizing with tangle bearing neurons in AD and Down's syndrome cortex [314].

COX elevations influence multiple downstream mechanisms of inflammation that are well known in the periphery (e.g. cytokine stimulation). Similar downstream mechanisms are likely to occur in the AD brain. This is supported by in vitro culture experiments indicating the production of prostaglandins in response to cytokines [34,284,313], as well as the altered expression of cytokines and other inflammation-related molecules in response to $\mathrm{PGE}^{2}[41,112,177,215]$ in as- 
trocytes and microglia. Other possible roles for COX2 in $\mathrm{AD}$ inflammation involve mechanisms related to glutamate excitotoxicity [192], free radicals [321], and PPAR $\gamma$ expression $[179,217,218,307,338]$.

\subsection{Blood coagulation and fibrinolysis systems}

Originally discovered as mechanisms that regulate the flow and coagulation of blood in the vasculature and at sites of vascular injury, the blood coagulation and fibrinolysis systems have more recently been recognized as playing important roles in inflammatory and tissue repair processes in extravascular tissues. Several molecules of the coagulation cascade, as well as numerous proteases, have been detected in $\mathrm{A} \beta$ plaques or are upregulated in the AD brain (Table 1). Interestingly, the actions of several of these mediators are enhanced by heparin binding [356,375]. For this reason, the conspicuous presence of heparin sulfate proteoglycans in $\mathrm{A} \beta$ plaques and neurofibrillary tangles in $\mathrm{AD}$ brains [376], lends credibility to the active involvement of these proteins in $\mathrm{AD}$ neuroinflammation.

\subsection{Adhesion molecules}

As part of the inflammatory response, altered expression of several intercellular adhesion molecules occurs on astrocytes and microglia (Table 1). Such molecules are especially abundant on $\mathrm{A} \beta$ plaque-associated astrocytes and microglia. Expression of many of these adhesion molecules is readily induced by upregulated cytokines (reviewed in [27,36,75,299,341]). Integrins are among the better studied adhesion molecules in AD. In particular, the $\beta 2$ integrins complement receptor 3 , complement receptor 4, and LFA-1, a ligand for ICAM1 on astrocytes [13], are significantly upregulated on AD microglia [347]. Accordingly, these molecules represent another mechanism for glial cell recruitment to inflammatory sites of $\mathrm{A} \beta$ deposition.

\subsection{Other inflammatory and acute phase proteins}

The acute phase proteins are a diverse set of molecules that arise early in inflammation as the acute phase response. Like many other inflammatory mediators, a wide range of acute phase reactants have been found in association with senile plaques and extracellular neurofibrillary tangles (Table 1).

A few of the acute phase proteins have notable interactions with $\mathrm{A} \beta . \quad \alpha 1$-antichymotrypsin $(\alpha 1$-ACT) is consistently colocalized with $\mathrm{A} \beta$ deposits in the
$\mathrm{AD}$ brain, and has been suggested to play a role in plaque formation by enhancing conversion of nonfibrillar forms of the $\mathrm{A} \beta$ to $\mathrm{A} \beta$ fibrils $[103,118,188$, 246]. Another acute phase protein, $\alpha 2$-macroglobulin $(\alpha 2-\mathrm{MAC})$, is a potent broad spectrum protease inhibitor possessing a bait region that acts as a substrate for a wide variety of proteases [47,378]. Formation of a protease/ $\alpha 2-$ MAC complex exposes a receptor-binding domain. The complex is removed by endocytosis following binding of this domain to the $\alpha 2-\mathrm{MAC}$ receptor/low density lipoprotein receptorrelated protein $(\alpha 2-\mathrm{MACR} / \mathrm{LRP})$. In addition to protease inhibition and protease removal, $\alpha 2-\mathrm{MAC}$ and $\alpha 2-M A C / L R P$ function as a clearance system for inflammatory proteins $[47,89,165,204,442] . \quad \alpha 2-\mathrm{MAC}$ and $\alpha 2-\mathrm{MAC} / \mathrm{LRP}$ have been found in neuritic plaque amyloid and neurofibrillary tangles $[33,336,384,408$, 447]. A $\beta$ also apparently forms a complex with $\alpha 2-$ MAC that is removed through $\alpha 2-\mathrm{MAC} / \mathrm{LRP}$ endocytic clearance mechanisms [305]. $\alpha 2-\mathrm{MAC}$ may inhibit A $\beta$ aggregation and fibril formation [87], promoting $\mathrm{A} \beta$ removal and further implicating $\alpha 2-\mathrm{MAC}$ and $\alpha 2-$ MAC/LRP in several AD pathophysiologic processes. Interestingly, polymorphisms in $\alpha 1$-ACT [188], $\alpha 2$ MAC [40], and $\alpha 2-M A C / L R P ~[189,222,332]$ receptor [189] genes have been reported to be possible risk factors for AD.

Apolipoprotein E (ApoE), particularly, the ApoE4 allele, has been widely documented to play a role in AD. Long-known to be upregulated at sites of inflammation and to play a role in peripheral amyloidosis [197], ApoE first came to light in AD as a susceptibility gene [387]. ApoE4 appears to shorten the onset of AD by some 5-10 years [387] and patients with one and, especially, two ApoE4 alleles tend to have more congophilic amyloid angiopathy [242]. In addition, ApoE can influence microglial expression of several inflammatory factors [209,210], and this effect appears to be isoform dependent [30,233].

Finally, soluble amyloid $\beta$ precursor protein $(\mathrm{sA} \beta \mathrm{PP})$ bears a number of properties in common with acute phase proteins. It is elevated at sites of tissue damage [29]; its synthesis and release are partly mediated by pro-inflammatory cytokines and stimuli [54, $135]$; and it induces NF- $\kappa \mathrm{B}$, stimulating the expression of several inflammatory mediators [30]. The proinflammatory activity of $\mathrm{sA} \beta \mathrm{PP}$ is inhibited by binding to ApoE, with ApoE3 being more effective than ApoE4. In contrast, it should be noted that $\mathrm{sA} \beta \mathrm{PP}$ has also been demonstrated to have neurotrophic actions in many systems [24,262,266,291,292,373,463]. 


\subsection{Free radicals}

There has been intense interest in the role of oxygen free radicals as a contributing factor to AD pathology [35,230,256,257]. Many hallmark modifications of oxidative damage have been demonstrated in the AD brain, including proteins modified with advanced glycation end products (AGEs) [396], malondialdehyde, 8hydroxy-deoxyguanosine, 4-hydroxynonenal [23,257], nitrotyrosine [140,374,391], nitrotyrosine-modified proteins [140,152,374,391], and increased amounts of lipid peroxidation [257]. Free radical-mediated stress not only leads to direct cellular injury, but may also influence neuronal integrity by triggering redox-sensitive, NF- $\kappa \mathrm{B}$-mediated transcription of various pro-inflammatory and/or apoptosis-related genes in surrounding cells [187].

Although the majority of research on $\mathrm{AD}$ oxidative stress has focused on neuronal generation of free radicals [35,264,267], the concept of free radical toxicity actually has its roots in inflammation biology, where the secretion of reactive oxygen and nitrogen species by inflammatory cells is a major mechanism for attacking opsonized targets. Activated microglia have the potential to produce large amounts of reactive oxygen species via nicotinamide adenine dinucleotide phosphate (NADPH) oxidase complex, a complex activated by $\mathrm{A} \beta$ peptide. Through such mechanisms, microglia serve as an alternative source of free radicals [83,200,201,271,416,417]. Recent data have also indicated that some plaque-associated microglia may be a source of the enzyme myeloperoxidase (MPO) in AD brains [337]. MPO catalyzes a reaction culminating in the production of hypochlorous acid, which can further react to generate several other reactive oxygen species.

\section{Conclusion}

The best evidence for the pathophysiologic relevance of $\mathrm{AD}$ inflammation is the sheer number of inflammatory mediators that have been found to be upregulated in the AD brain (Table 1). The presence of these mediators defines a localized, innate inflammatory response with roots that are as obvious as those in a peripheral wound: damaged tissue and highly insoluble deposits of abnormal materials. That this localized, innate inflammatory response causes secondary damage to the affected tissue is inarguable if a century of peripheral inflammation biology has any meaning. The salient questions are how much secondary damage occurs due to $\mathrm{AD}$ inflammation, and how likely is it that the inflammatory mechanisms invoked, feed back to stimulate $\mathrm{AD}$ etiologic processes such as $\mathrm{A} \beta$ deposition. Given the recent interest in AD inflammation research, the answers to these questions should not take long to obtain.

\section{Acknowledgements}

Preparation of this review was supported by NIA AGO7367, the Alzheimer's Association, and the State of Arizona Alzheimer's Disease Research Center.

\section{References}

[1] C.R. Abraham, D.J. Selkoe and H. Potter, Immunochemical identification of the serine protease inhibitor alpha 1- antichymotrypsin in the brain amyloid deposits of Alzheimer's disease, Cell 52 (1988), 487-501.

[2] C.R. Abraham, T. Shirahama and H. Potter, Alpha 1antichymotrypsin is associated solely with amyloid deposits containing the beta-protein. Amyloid and cell localization of alpha 1-antichymotrypsin, Neurobiol Aging 11 (1990), 123129.

[3] D.O. Adams and T.A. Hamilton, Molecular basis of macrophage activation, in: The macrophage, C.E. Lewis and J.O. McGee, eds, IRL, Oxford, UK, 1992, pp. 75-114.

[4] A. Afagh, B.J. Cummings, D.H. Cribbs, C.W. Cotman and A.J. Tenner, Localization and cell association of $\mathrm{C} 1 \mathrm{q}$ in Alzheimer's disease brain, Exp Neurol 138 (1996), 22-32.

[5] F. Aguado, J. Ballabriga, E. Pozas and I. Ferrer, TrkA immunoreactivity in reactive astrocytes in human neurodegenerative diseases and colchicine-treated rats, Acta Neuropathol 96 (1998), 495-501.

[6] P.S. Aisen and K.L. Davis, Inflammatory mechanisms in Alzheimer's disease: implications for therapy, Am. J. Psychiatry 151 (1994), 1105-1113.

[7] H. Akiyama, Inflammatory response in Alzheimer's disease, Tohoku. J. Exp Med. 174 (1994), 295-303.

[8] H. Akiyama, [Thrombin deposition in brains of patients with Alzheimer's disease - activation of the coagulation system in the central nervous system], Rinsho. Byori. 104 (1997), 117-123.

[9] H. Akiyama, K. Ikeda, M. Katoh, E.G. McGeer and P.L. McGeer, Expression of MRP14, 27E10, interferon-alpha and leukocyte common antigen by reactive microglia in postmortem human brain tissue, J. Neuroimmunol. 50 (1994), 195-201.

[10] H. Akiyama, K. Ikeda, H. Kondo, M. Kato and P.L. McGeer, Microglia express the type 2 plasminogen activator inhibitor in the brain of control subjects and patients with Alzheimer's disease, Neurosci. Lett. 164 (1993), 233-235.

[11] H. Akiyama, K. Ikeda, H. Kondo and P.L. McGeer, Thrombin accumulation in brains of patients with Alzheimer's disease, Neurosci. Lett. 146 (1992), 152-154.

[12] H. Akiyama, T. Kawamata, S. Dedhar and P.L. McGeer, Immunohistochemical localization of vitronectin, its receptor and beta-3 integrin in Alzheimer brain tissue, J. Neuroimmunol. 32 (1991), 19-28. 
[13] H. Akiyama, T. Kawamata, T. Yamada, I. Tooyama, T. Ishii and P.L. McGeer, Expression of intercellular adhesion molecule (ICAM)-1 by a subset of astrocytes in Alzheimer disease and some other degenerative neurological disorders, Acta Neuropathol. (Berl.) 85 (1993), 628-634.

[14] H. Akiyama, H. Kondo, K. Ikeda, T. Arai, M. Kato and P.L. McGleer, Immunohistochemical detection of coagulation factor XIIIa in postmortem human brain tissue, Neurosci. Lett. 202 (1995), 29-32.

[15] H. Akiyama and P.L. McGeer, Brain microglia constitutively express beta-2 integrins, J. Neuroimmunol. 30 (1990), 81-93.

[16] H. Akiyama, T. Nishimura, H. Kondo, K. Ikeda, Y. Hayashi and P.L. McGeer, Expression of the receptor for macrophage colony stimulating factor by brain microglia and its upregulation in brains of patients with Alzheimer's disease and amyotrophic lateral sclerosis, Brain Res 639 (1994), 171-174.

[17] H. Akiyama, I. Tooyama, T. Kawamata, K. Ikeda and P.L. McGeer, Morphological diversities of CD44 positive astrocytes in the cerebral cortex of normal subjects and patients with Alzheimer's disease, Brain Res 632 (1993), 249-259.

[18] H. Akiyama, T. Yamada, T. Kawamata and P.L. McGeer, Association of amyloid P component with complement proteins in neurologically diseased brain tissue, Brain Res 548 (1991), 349-352.

[19] Y. Akwa, D.E. Hassett and M.L. Eloranta et al., Transgenic expression of IFN-alpha in the central nervous system of mice protects against lethal neurotropic viral infection but induces inflammation and neurodegeneration, J. Immunol. 161 (1998), 5016-5026.

[20] S.J. Allen, G.K. Wilcock and D. Dawbarn, Profound and selective loss of catalytic TrkB immunoreactivity in Alzheimer's disease, Biochem. Biophys. Res Commun. 264 (1999), 648-651.

[21] D.F. Alonso, E.F. Farias, A.L. Famulari, R.O. Dominguez, S. Kohan and E.S. de Lustig, Excessive urokinase-type plasminogen activator activity in the euglobulin fraction of patients with Alzheimer-type dementia, J. Neurol Sci. 139 (1996), 83-88.

[22] A.J. Anderson, B.J. Cummings and C.W. Cotman, Increased immunoreactivity for Jun- and Fos-related proteins in Alzheimer's disease: association with pathology, Exp Neurol 125 (1994), 286-295.

[23] Y. Ando, T. Brannstrom and K. Uchida et al., Histochemical detection of 4-hydroxynonenal protein in Alzheimer amyloid, J. Neurol. Sci. 156 (1998), 172-176.

[24] W. Araki, N. Kitaguchi and Y. Tokushima et al., Trophic effect of beta-amyloid precursor protein on cerebral cortical neurons in culture, Biochem. Biophys. Res. Commun. 181 (1991), 265-271.

[25] D.M. Araujo and P.A. Lapchak, Induction of immune system mediators in the hippocampal formation in Alzheimer's and Parkinson's diseases: selective effects on specific interleukins and interleukin receptors, Neuroscience 61 (1994), 745-754.

[26] M.D. Ard, G.M. Cole, J. Wei, A.P. Mehrle and J.D. Fratkin, Scavenging of Alzheimer's Amyloid $\beta$-protein by microglia in culture, J. Neurosci. Res. 43 (1996), 190-202.

[27] B. Arvin, L.F. Neville, F.C. Barone and G.Z. Feuerstein, The role of inflammation and cytokines in brain injury, Neurosci. Biobehav. Rev. 20 (1996), 445-452.

[28] L. Balazs and M. Leon, Evidence of an oxidative challenge in the Alzheimer's brain, Neurochem. Res 19 (1994), 11311137.
[29] R.B. Banati, J. Gehrmann and G.W. Kreutzberg, Glial betaamyloid precursor protein: expression in the dentate gyrus after entorhinal cortex lesion, Neuroreport. 5 (1994), 13591361 .

[30] S.W. Barger and A.D. Harmon, Microglial activation by Alzheimer amyloid precursor protein and modulation by apolipoprotein E, Nature 388 (1997), 878-881.

[31] K.D. Barron, The microglial cell. A historical review, J. Neurol Sci. 134 (1995), 57-68.

[32] J. Bauer, G. Konig and S. Strauss et al., In-vitro matured human macrophages express Alzheimer's beta A4-amyloid precursor protein indicating synthesis in microglial cells, FEBS Lett. 282 (1991), 335-340.

[33] J. Bauer, S. Strauss and U. Schreiter-Gasser et al., Interleukin-6 and alpha-2-macroglobulin indicate an acutephase state in Alzheimer's disease cortices, FEBS Lett. 285 (1991), 111-114

[34] M.K. Bauer, K. Lieb and K. Schulze-Osthoff et al., Expression and regulation of cyclooxygenase- 2 in rat microglia, Eur. J. Biochem. 243 (1997), 726-731.

[35] C. Behl, Alzheimer's disease and oxidative stress: implications for novel therapeutic approaches, Prog. Neurobiol 57 (1999), 301-323.

[36] E.N. Benveniste, B.S. Huneycutt, P. Shrikant and M.E. Ballestas, Second messenger systems in the regulation of cytokines and adhesion molecules in the central nervous system, Brain Behav. Immun. 9 (1995), 304-314.

[37] T.M. Berzin, B.D. Zipser and M.S. Rafii et al., Agrin and microvascular damage in Alzheimer's disease, Neurobiol Aging 21 (2000), 349-355.

[38] E. Birecree, W.O.J. Whetsell, C. Stoscheck, L.E.J. King and L.B. Nanney, Immunoreactive epidermal growth factor receptors in neuritic plaques from patients with Alzheimer's disease, J. Neuropathol Exp Neurol 47 (1988), 549-560.

[39] L. Bitting, A. Naidu, B. Cordell and G.M.J. Murphy, $\beta$ amyloid peptide secretion by a microglial cell line is induced by b-amyloid (25-35) and lipopolysaccharide, J. Biol. Chem. 271 (1996), 16084-16089.

[40] D. Blacker, M.A. Wilcox and N.M. Laird et al., Alpha-2 macroglobulin is genetically associated with Alzheimer disease, Nat. Genet. 19 (1998), 357-360.

[41] M.A. Blom, M.G. van Twillert and S.C. de Vries et al., NSAIDS inhibit the IL-1 beta-induced IL-6 release from human post- mortem astrocytes: the involvement of prostaglandin E2, Brain Res. 777 (1997), 210-218.

[42] D. Blum-Degen, T. Muller, W. Kuhn, M. Gerlach, H. Przuntek and P. Riederer, Interleukin- 1 beta and interleukin- 6 are elevated in the cerebrospinal fluid of Alzheimer's and de novo Parkinson's disease patients, Neurosci. Lett. 202 (1995), 1720.

[43] F. Boissiere, B. Faucheux, M. Ruberg, Y. Agid and E.C. Hirsch, Decreased TrkA gene expression in cholinergic neurons of the striatum and basal forebrain of patients with Alzheimer's disease, Exp Neurol 145 (1997), 245-252.

[44] F. Boissiere, S. Hunot and B. Faucheux et al., Nuclear translocation of NF-kappaB in cholinergic neurons of patients with Alzheimer's disease, Neuroreport. 8 (1997), 2849-2852.

[45] F. Boissiere, S. Hunot, B. Faucheux, L.B. Hersh, Y. Agid and E.C. Hirsch, Trk neurotrophin receptors in cholinergic neurons of patients with Alzheimer's disease, Dement. Geriatr. Cogn. Disord. 8 (1997), 1-8.

[46] F. Boissiere, S. Lehericy, O. Strada, Y. Agid and E.C. Hirsch, Neurotrophin receptors and selective loss of cholinergic neu- 
rons in Alzheimer disease, Mol. Chem. Neuropathol 28 (1996), 219-223.

[47] W. Borth, $\alpha 2$-macroglobulin, a multifunctional binding protein with targeting characteristics, FASEB J. 6 (1992), 33453353.

[48] G.I. Botchkina, M.E. Meistrell, I.L. Botchkina and K.J. Tracey, Expression of TNF and TNF receptors (p55 and p75) in the rat brain after focal cerebral ischemia, Mol. Med. 3 (1997), 765-781.

[49] L. Brachova, L.F. Lue, J. Schultz, T. el Rashidy and J. Rogers, Association cortex, cerebellum, and serum concentrations of C1q and factor B in Alzheimer's disease, Brain Res Mol. Brain Res 18 (1993), 329-334.

[50] B.M. Bradt, W.P. Kolb and N.R. Cooper, Complementdependent proinflammatory properties of the Alzheimer's disease beta-peptide, J. Exp. Med. 188 (1998), 431-438.

[51] C.D. Breder, M. Tsujimoto, Y. Terano, D.W. Scott and C.B. Saper, Distribution and characterization of tumor necrosis factor-alpha-like immunoreactivity in the murine central nervous system, J. Comp. Neurol. 337 (1993), 543-567.

[52] F.M. Brett, A.P. Mizisin, H.C. Powell and I.L. Campbell, Evolution of neuropathologic abnormalities associated with blood-brain barrier breakdown in transgenic mice expressing interleukin-6 in astrocytes, J. Neuropathol. Exp Neurol 54 (1995), 766-775.

[53] G.A. Broe, A.S. Henderson and H. Creasey et al., A casecontrol study of Alzheimer's disease in Australia, Neurology 40 (1990), 1698-1707.

[54] J.D. Buxbaum, K.N. Liu and Y. Luo et al., Evidence that tumor necrosis factor alpha converting enzyme is involved in regulated alpha-secretase cleavage of the Alzheimer amyloid protein precursor, J. Biol. Chem. 273 (1998), 27765-27767.

[55] R. Cacabelos, X.A. Alvarez and L. Fernandez-Novoa et al., Brain interleukin-1 beta in Alzheimer's disease and vascular dementia, Methods Find. Exp Clin. Pharmacol. 16 (1994), $141-151$

[56] R. Cacabelos, X.A. Alvarez, A. Franco-Maside, L. Fernandez-Novoa and J. Caamano, Serum tumor necrosis factor (TNF) in Alzheimer's disease and multi-infarct dementia, Methods Find. Exp Clin. Pharmacol. 16 (1994), 29 35.

[57] A. Castano, L.J. Lawson, S. Fearn and V.H. Perry, Activation and proliferation of murine microglia are insensitive to glucocorticoids in Wallerian degeneration, Eur. J. Neurosci. 8 (1996), 581-588.

[58] J.W. Chang, P.D. Coleman and M.K. O'Banion, Prostaglandin G/H synthase-2 (cyclooxygenase-2) mRNA expression is decreased in Alzheimer's disease, Neurobiol Aging 17 (1996), 801-808.

[59] C.C. Chao, T.A. Ala and S. Hu et al., Serum cytokine levels in patients with Alzheimer's disease, Clin. Diagn. Lab. Immunol. 1 (1994), 433-436.

[60] C.C. Chao, S. Hu, W.H. Frey, T.A. Ala, W.W. Tourtellotte and P.K. Peterson, Transforming growth factor beta in Alzheimer's disease, Clin. Diagn. Lab. Immunol. 1 (1994), 109-110.

[61] C.C. Chao, S. Hu, T.W. Molitor, E.G. Shaskan and P.K. Peterson, Activated microglia mediate neuronal cell injury via a nitric oxide mechanism, J. Immunol. 149 (1992), 27362741.

[62] C.C. Chao, S. Hu, W.S. Sheng, F.H. Kravitz and P.K. Peterson, Inflammation-mediated neuronal cell injury, in: Inflammatory cells and mediators in CNS diseases, R.R. Ruffolo,
G.Z. Feuerstain, A.J. Hunter, G. Poste and B.W. Metcalf, eds, Harwood Academic Publishers, Canada, 1999, pp. 483-495.

[63] S. Chen, R.C. Frederickson and K.R. Brunden, Neuroglialmediated immunoinflammatory responses in Alzheimer's disease: complement activation and therapeutic approaches, Neurobiol. Aging 17 (1996), 781-787.

[64] N.H. Choi-Miura, Y. Ihara and K. Fukuchi et al., SP-40,40 is a constituent of Alzheimer's amyloid, Acta Neuropathol. (Berl.) 83 (1992), 260-264.

[65] B.H. Choi, R.C. Kim and P.J. Vaughan et al., Decreases in protease nexins in Alzheimer's disease brain, Neurobiol Aging 16 (1995), 557-562.

[66] R.H. Christie, M. Freeman and B.T. Hyman, Expression of the macrophage scavenger receptor, a multifunctional lipoprotein receptor, in microglia associated with senile plaques in Alzheimer's disease, Am. J. Pathol. 148 (1996), 399-403.

[67] C.K. Combs, D.E. Johnson, S.B. Cannady, T.M. Lehman and G.E. Landreth, Identification of microglial signal transduction pathways mediating a neurotoxic response to amyloidogenic fragments of beta-amyloid and prion proteins, $J$. Neurosci. 19 (1999), 928-939.

[68] C.K. Combs, D.E. Johnson, J.C. Karlo, S.B. Cannady and G.E. Landreth, Inflammatory mechanisms in Alzheimer's disease: inhibition of beta-amyloid-stimulated proinflammatory responses and neurotoxicity by PPARgamma agonists, J. Neurosci. 20 (2000), 558-567.

[69] B. Connor, E.J. Beilharz and C. Williams et al., Insulin-like growth factor-I (IGF-I) immunoreactivity in the Alzheimer's disease temporal cortex and hippocampus, Brain Res Mol. Brain Res 49 (1997), 283-290.

[70] B. Connor, D. Young and P. Lawlor et al., Trk receptor alterations in Alzheimer's disease, Brain Res Mol. Brain Res 42 (1996), 1-17.

[71] B. Connor, D. Young, Q. Yan, R.L. Faull, B. Synek and M. Dragunow, Brain-derived neurotrophic factor is reduced in Alzheimer's disease, Brain Res Mol. Brain Res 49 (1997), 71-81.

[72] J.R. Connor, P. Tucker, M. Johnson and B. Snyder, Ceruloplasmin levels in the human superior temporal gyrus in aging and Alzheimer's disease, Neurosci. Lett. 159 (1993), 88-90.

[73] F. Coria, E. Castano and F. Prelli et al., Isolation and characterization of amyloid P component from Alzheimer's disease and other types of cerebral amyloidosis, Lab. Invest. 58 (1988), 454-458.

[74] F. Coria, A. Moreno, I. Rubio, M.A. Garcia, E. Morato and F.J. Mayor, The cellular pathology associated with Alzheimer beta-amyloid deposits in non-demented aged individuals, Neuropathol. Appl. Neurobiol. 19 (1993), 261-268.

[75] C.W. Cotman, N.P. Hailer, K.K. Pfister, I. Soltesz and M. Schachner, Cell adhesion molecules in neural plasticity and pathology: similar mechanisms, distinct organizations? Prog. Neurobiol 55 (1998), 659-669.

[76] C.W. Cotman and A.J. Tenner, $\beta$-amyloid converts an acute phase injury response to chronic injury response, Neurobiol. Aging 17 (1996), 723-731.

[77] K.A. Crutcher, S.A. Scott, S. Liang, W.V. Everson and J. Weingartner, Detection of NGF-like activity in human brain tissue: increased levels in Alzheimer's disease, J. Neurosci. 13 (1993), 2540-2550.

[78] B.J. Cummings, J.H. Su and C.W. Cotman, Neuritic involvement within bFGF immunopositive plaques of Alzheimer's disease, Exp Neurol 124 (1993), 315-325. 
[79] J.B. Davis, H.F. McMurray and D. Schubert, The amyloid beta-protein of Alzheimer's disease is chemotactic for mononuclear phagocytes, Biochem. Biophys. Res. Commun. 189 (1992), 1096-1100.

[80] N. Davoust, J. Jones, P.F. Stahel, R.S. Ames and S.R. Barnum, Receptor for the $\mathrm{C} 3 \mathrm{a}$ anaphylatoxin is expressed by neurons and glial cells, Glia 26 (1999), 201-211.

[81] V.L. Dawson and T.M. Dawson, Nitric oxide neurotoxicity, J. Chem. Neuroanat. 10 (1996), 179-190.

[82] S.M. de la Monte, Y.K. Sohn and J.R. Wands, Correlates of p53- and Fas (CD95)-mediated apoptosis in Alzheimer's disease, J. Neurol Sci. 152 (1997), 73-83.

[83] V. Della-Bianca, S. Dusi, E. Bianchini, I. Dal-Pra and F. Rossi, $\beta$ amyloid activates the $\mathrm{O}_{2}$ forming NADPH oxidase in microglia, monocytes and neutrophils. A possible inflammatory mechanism of neuronal damage in Alzheimer's disease, J. Biol. Chem. 274 (1999), 15493-15499.

[84] D.A. DeWitt, G. Perry, M. Cohen, C. Doller and J. Silver, Astrocytes regulate microglial phagocytosis of senile plaque cores of Alzheimer's disease, Exp. Neurol. 149 (1998), 329_ 340 .

[85] D.W. Dickson, J. Farlo, P. Davies, H. Crystal, P. Fuld and S.H. Yen, Alzheimer's disease. A double-labeling immunohistochemical study of senile plaques, Am. J. Pathol. 132 (1988), 86-101.

[86] D.W. Dickson, S.C. Lee, L.A. Mattiace, S.H. Yen and C. Brosnan, Microglia and cytokines in neurological disease, with special reference to AIDS and Alzheimer's disease, Glia 7 (1993), 75-83.

[87] Y. Du, K.R. Bales and R.C. Dodel et al., Alpha2macroglobulin attenuates beta-amyloid peptide 1-40 fibril formation and associated neurotoxicity of cultured fetal rat cortical neurons, J. Neurochem. 70 (1998), 1182-1188.

[88] Y. Du, R.C. Dodel and B.J. Eastwood, Association of an interleukin- $1 \alpha$ polymorphism with Alzheimer's disease, Neurology (2000), in press.

[89] Y. Du, B. Ni and M. Glinn et al., alpha2-Macroglobulin as a beta-amyloid peptide-binding plasma protein, J. Neurochem. 69 (1997), 299-305.

[90] P.E. Duffy, M. Rapport and L. Graf, Glial fibrillary acidic protein and Alzheimer-type senile dementia, Neurology 30 (1980), 778-782.

[91] T. Duong, M. Nikolaeva and P.J. Acton, C-reactive proteinlike immunoreactivity in the neurofibrillary tangles of Alzheimer's disease, Brain Res 749 (1997), 152-156.

[92] T. Duong, E.C. Pommier and A.B. Scheibel, Immunodetection of the amyloid P component in Alzheimer's disease, Acta Neuropathol. (Berl.) 78 (1989), 429-437.

[93] M. Eddleston and L. Mucke, Molecular profile of reactive astrocytes - implications for their role in neurologic disease, Neuroscience 54 (1993), 15-36.

[94] W.D. Ehmann, W.R. Markesbery, M. Alauddin, T.I. Hossain and E.H. Brubaker, Brain trace elements in Alzheimer's disease, Neurotoxicology 7 (1986), 195-206.

[95] P. Eikelenboom, C.E. Hack, J.M. Rozemuller and F.C. Stam, Complement activation in amyloid plaques in Alzheimer's dementia, Virchows Arch. B. Cell Pathol. Incl. Mol. Pathol. 56 (1989), 259-262.

[96] P. Eikelenboom, J.M. Rozemuller and G. Kraal et al., Cerebral amyloid plaques in Alzheimer's disease but not in scrapie-affected mice are closely associated with a local inflammatory process, Virchows Arch. B. Cell Pathol. Incl. Mol. Pathol. 60 (1991), 329-336.
[97] P. Eikelenboom and F.C. Stam, Immunoglobulins and complement factors in senile plaques. An immunoperoxidase study, Acta Neuropathol. (Berl.) 57 (1982), 239-242.

[98] P. Eikelenboom and F.C. Stam, An immunohistochemical study on cerebral vascular and senile plaque amyloid in Alzheimer's dementia, Virchows Arch. B. Cell Pathol. 47 (1984), 17-25.

[99] P. Eikelenboom, S.S. Zhan, W. Kamphorst, V. d. van and J.M. Rozemuller, Cellular and substrate adhesion molecules (integrins) and their ligands in cerebral amyloid plaques in Alzheimer's disease, Virchows Arch. 424 (1994), 421-427.

[100] J. El Khoury, S.E. Hickman, C.A. Thomas, L. Cao, S.C. Silverstein and J.D. Loike, Scavenger receptor-mediated adhesion of microglia to beta-amyloid fibrils, Nature 382 (1996), 716-719.

[101] J. El Khoury, S.E. Hickman, C.A. Thomas, J.D. Loike and S.C. Silverstein, Microglia, scavenger receptors, and the pathogenesis of Alzheimer's disease, Neurobiol. Aging 19 (1998), S81-S84.

[102] I. Elovaara, C.P. Maury and J. Palo, Serum amyloid A protein, albumin and prealbumin in Alzheimer's disease and in demented patients with Down's syndrome, Acta Neurol Scand 74 (1986), 245-250.

[103] S. Eriksson, S. Janciauskiene and L. Lannfelt, Alpha 1antichymotrypsin regulates Alzheimer beta-amyloid peptide fibril formation, Proc. Natl. Acad. Sci. USA 92 (1995), 23132317

[104] M.G. Espey, O.N. Chernyshev, J.F.J. Reinhard, M.A. Namboodiri and C.A. Colton, Activated human microglia produce the excitotoxin quinolinic acid, Neuroreport. 8 (1997), 431-434.

[105] M. Fahnestock, S.A. Scott, N. Jette, J.A. Weingartner and K.A. Crutcher, Nerve growth factor mRNA and protein levels measured in the same tissue from normal and Alzheimer's disease parietal cortex, Brain Res Mol. Brain Res 42 (1996), $175-178$.

[106] L. Feng, Y. Xia, G.E. Garcia, D. Hwang and C.B. Wilson, Involvement of reactive oxygen intermediates in cyclooxygenase- 2 expression induced by interleukin-1, tumor necrosis factor-alpha, and lipopolysaccharide, J. Clin. Invest. 95 (1995), 1669-1675.

[107] H. Fenton, P.W. Finch and J.S. Rubin et al., Hepatocyte growth factor (HGF/SF) in Alzheimer's disease, Brain Res 779 (1998), 262-270.

[108] I. Ferrer, C. Marin and M.J. Rey et al., BDNF and fulllength and truncated TrkB expression in Alzheimer disease. Implications in therapeutic strategies, J. Neuropathol Exp Neurol 58 (1999), 729-739.

[109] I. Ferrer and E. Marti, Distribution of fibroblast growth factor receptor-1 (FGFR-1) and FGFR-3 in the hippocampus of patients with Alzheimer's disease, Neurosci. Lett. 240 (1998), 139-142.

[110] I. Ferrer, E. Marti, E. Lopez and A. Tortosa, NF-kB immunoreactivity is observed in association with beta A4 diffuse plaques in patients with Alzheimer's disease, Neuropathol Appl. Neurobiol 24 (1998), 271-277.

[111] I. Ferrer, J. Segui and A.M. Planas, Amyloid deposition is associated with c-Jun expression in Alzheimer's disease and amyloid angiopathy, Neuropathol Appl. Neurobiol 22 (1996), 521-526.

[112] B.L. Fiebich, M. Hull, K. Lieb, K. Gyufko, M. Berger and J. Bauer, Prostaglandin E2 induces interleukin-6 synthesis in human astrocytoma cells, J. Neurochem. 68 (1997), 704-709. 
[113] H. Fillit, W.H. Ding and L. Buee et al., Elevated circulating tumor necrosis factor levels in Alzheimer's disease, Neurosci. Lett. 129 (1991), 318-320.

[114] B. Fischer and A. Popa-Wagner, [Alzheimer disease: involvement of the complement system in cell death. Gene expression of $\mathrm{C} 1 \mathrm{q}$ and $\mathrm{C} 3$ in the frontal cortex of patients with Alzheimer disease and control probands] Morbus Alzheimer: Beteiligung des Komplementsystems am Zelluntergang. Genexpression von Komplement C1q und C3 im frontalen Kortex von Alzheimer-Patienten und Kontrollpersonen, Fortschr. Med. 114 (1996), 161-163.

[115] B. Fischer, H. Schmoll, P. Riederer, J. Bauer, D. Platt and A. Popa-Wagner, Complement C1q and C3 mRNA expression in the frontal cortex of Alzheimer's patients, J. Mol. Med. 73 (1995), 465-471.

[116] K.C. Flanders, C.F. Lippa, T.W. Smith, D.A. Pollen and M.B. Sporn, Altered expression of transforming growth factor-beta in Alzheimer's disease, Neurology 45 (1995), 1561-1569.

[117] J. Fleming and J.G. Joshi, Ferritin: isolation of aluminumferritin complex from brain, Proc. Natl. Acad. Sci. USA 84 (1987), 7866-7870.

[118] P.E. Fraser, J.T. Nguyen, D.R. McLachlan, C.R. Abraham and D.A. Kirschner, Alpha 1-antichymotrypsin binding to Alzheimer A beta peptides is sequence specific and induces fibril disaggregation in vitro, J. Neurochem. 61 (1993), 298305.

[119] S.A. Frautschy, G.M. Cole and A. Baird, Phagocytosis and deposition of vascular beta-amyloid in rat brains injected with Alzheimer beta-amyloid, Am. J. Pathol. 140 (1992), 1389-1399.

[120] S.A. Frautschy, F. Yang and M. Irrizarry et al., Microglial response to amyloid plaques in APPsw transgenic mice, Am. J. Pathol. 152 (1998), 307-317.

[121] E.M. Frohman, T.C. Frohman, S. Gupta, A. de Fougerolles and S. van den Noort, Expression of intercellular adhesion molecule 1 (ICAM-1) in Alzheimer's disease, J. Neurol Sci. 106 (1991), 105-111.

[122] A. Garlind, A. Brauner, B. Hojeberg, H. Basun and M. Schultzberg, Soluble interleukin-1 receptor type II levels are elevated in cerebrospinal fluid in Alzheimer's disease patients, Brain Res 826 (1999), 112-116.

[123] P. Gasque, P. Chan and M. Fontaine et al., Identification and characterization of the complement C5a anaphylatoxin receptor on human astrocytes, J. Immunol. 155 (1995), 48824889.

[124] P. Gasque, M. Fontaine and B.P. Morgan, Complement expression in human brain. Biosynthesis of terminal pathway components and regulators in human glial cells and cell lines, Journal of Immunology 154 (1995), 4726-4733.

[125] P. Gasque, A. Ischenko, J. Legoedec, C. Mauger, M.T. Schouft and M. Fontaine, Expression of the complement classical pathway by human glioma in culture. A model for complement expression by nerve cells, J. Biol. Chem. $\mathbf{2 6 8}$ (1993), 25068-25074.

[126] P. Gasque, S.K. Singhrao, J.W. Neal, O. Gotze and B.P. Morgan, Expression of the receptor for complement C5a (CD88) is up-regulated on reactive astrocytes, microglia, and endothelial cells in the inflamed human central nervous system, Am. J. Pathol. 150 (1997), 31-41.

[127] W.F. Gattaz, N.J. Cairns, R. Levy, H. Forstl, D.F. Braus and A. Maras, Decreased phospholipase A2 activity in the brain and in platelets of patients with Alzheimer's disease, Eur. Arch. Psychiatry Clin. Neurosci. 246 (1996), 129-131.
[128] W.F. Gattaz, A. Maras, N.J. Cairns, R. Levy and H. Forstl, Decreased phospholipase A2 activity in Alzheimer brains, Biol. Psychiatry 37 (1995), 13-17.

[129] J. Gehrmann, G. Mies and P. Bonnekoh et al., Microglial reaction in the rat cerebral cortex induced by cortical spreading depression, Brain Pathol. 3 (1993), 11-17.

[130] H. Gewurz, S.C. Ying, H. Jiang and T.F. Lint, Nonimmune activation of the classical complement pathway, Behring. Inst. Mitt. (1993), 138-147.

[131] P. Giannakopoulos, E. Kovari, L.E. French, I. Viard, P.R. Hof and C. Bouras, Possible neuroprotective role of clusterin in Alzheimer's disease: a quantitative immunocytochemical study, Acta Neuropathol (Berl.) 95 (1998), 387-394.

[132] A.M. Gillian, J.P. Brion and K.C. Breen, Expression of the neural cell adhesion molecule (NCAM) in Alzheimer's disease, Neurodegeneration 3 (1994), 283-291.

[133] B. Giometto, V. Argentiero, F. Sanson, G. Ongaro and B. Tavolato, Acute-phase proteins in Alzheimer's disease, Eur. Neurol 28 (1988), 30-33.

[134] D. Giulian, Ameboid microglia as effectors of inflammation in the central nervous system, J. Neurosci. Res 18 (1987), $155-153$.

[135] D. Goldgaber, H.W. Harris and T. Hla et al., Interleukin 1 regulates synthesis of amyloid beta-protein precursor mRNA in human endothelial cells, Proc. Natl. Acad. Sci. USA 86 (1989), 7606-7610.

[136] P.A. Gollin, R.N. Kalaria, P. Eikelenboom, A. Rozemuller and G. Perry, Alpha 1-antitrypsin and alpha 1antichymotrypsin are in the lesions of Alzheimer's disease, Neuroreport. 3 (1992), 201-203.

[137] F. Gomez-Pinilla, B.J. Cummings and C.W. Cotman, Induction of basic fibroblast growth factor in Alzheimer's disease pathology, Neuroreport. 1 (1990), 211-214.

[138] C. Gong, Z. Qin, A.L. Betz, X.H. Liu and G.Y. Yang, Cellular localization of tumor necrosis factor alpha following focal cerebral ischemia in mice, Brain Res. 801 (1998), 1-8.

[139] P.F. Good, D.P. Perl, L.M. Bierer and J. Schmeidler, Selective accumulation of aluminum and iron in the neurofibrillary tangles of Alzheimer's disease: a laser microprobe (LAMMA) study, Ann. Neurol 31 (1992), 286-292.

[140] P.F. Good, P. Werner, A. Hsu, C.W. Olanow and D.P. Perl, Evidence of neuronal oxidative damage in Alzheimer's disease, Am. J. Pathol. 149 (1996), 21-28.

[141] W.S. Griffin, J.G. Sheng, G.W. Roberts and R.E. Mrak, Interleukin-1 expression in different plaque types in Alzheimer's disease: significance in plaque evolution, $J$. Neuropathol. Exp. Neurol. 54 (1995), 276-281.

[142] W.S. Griffin, J.G. Sheng and M.C. Royston et al., Glialneuronal interactions in Alzheimer's disease: the potential role of a 'cytokine cycle' in disease progression, Brain Pathol. 8 (1998), 65-72.

[143] W.S. Griffin, L.C. Stanley and C. Ling et al., Brain interleukin 1 and S-100 immunoreactivity are elevated in Down syndrome and Alzheimer disease, Proc. Natl. Acad. Sci. USA 86 (1989), 7611-7615.

[144] W.S.T. Griffin, J.G. Sheng and R.E. Mrak, Inflammatory pathways. Implications in Alzheimer's disease, in: Molecular mechanisms of dementia., W. Wasco and R.E. Tanzi, eds, Humana Press Inc., Totowa, NJ, 1997, pp. 169-176.

[145] I. Grundke-Iqbal, J. Fleming, Y.C. Tung, H. Lassmann, K. Iqbal and J.G. Joshi, Ferritin is a component of the neuritic (senile) plaque in Alzheimer dementia, Acta Neuropathol (Berl.) 81 (1990), 105-110. 
[146] S. Haga, T. Aizawa, T. Ishii and K. Ikeda, Complement gene expression in mouse microglia and astrocytes in culture: comparisons with mouse peritoneal macrophages, Neurosci. Lett. 216 (1996), 191-194.

[147] H. Hampel, T. Sunderland and H.U. Kotter et al., Decreased soluble interleukin-6 receptor in cerebrospinal fluid of patients with Alzheimer's disease, Brain Res. 780 (1998), 356359.

[148] H. Hampel, S.J. Teipel and F. Padberg et al., Discriminant power of combined cerebrospinal fluid tau protein and of the soluble interleukin-6 receptor complex in the diagnosis of Alzheimer's disease, Brain Res. 823 (1999), 104-112.

[149] L.A. Hansen, D.M. Armstrong and R.D. Terry, An immunohistochemical quantification of fibrous astrocytes in the aging human cerebral cortex, Neurobiol Aging 8 (1987), 1-6.

[150] S.D. Harr, L. Uint, R. Hollister, B.T. Hyman and A.J. Mendez, Brain expression of apolipoproteins E, J, and A-I in Alzheimer's disease, J. Neurochem. 66 (1996), 2429-2435.

[151] R. Hellweg, C.A. Gericke, K. Jendroska, H.D. Hartung and J. Cervos-Navarro, NGF content in the cerebral cortex of nondemented patients with amyloid-plaques and in symptomatic Alzheimer's disease, Int. J. Dev. Neurosci. 16 (1998), 787794.

[152] K. Hensley, M.L. Maidt, Z. Yu, H. Sang, W.R. Markesbery and R.A. Floyd, Electrochemical analysis of protein nitrotyrosine and dityrosine in the Alzheimer brain indicates regionspecific accumulation, J. Neurosci. 18 (1998), 8126-8132.

[153] C.J. Heyser, E. Masliah, A. Samimi, I.L. Campbell and L.H. Gold, Progressive decline in avoidance learning paralleled by inflammatory neurodegeneration in transgenic mice overexpressing interleukin 6 in the brain, Proc. Natl. Acad. Sci. 94 (1997), 1500-1505.

[154] G.A. Higgins and E.J. Mufson, NGF receptor gene expression is decreased in the nucleus basalis in Alzheimer's disease, Exp Neurol 106 (1989), 222-236.

[155] L. Ho, C. Pieroni, D. Winger, D.P. Purohit, P.S. Aisen and G.M. Pasinetti, Regional distribution of cyclooxygenase- 2 in the hippocampal formation in Alzheimer's disease, $\mathrm{J}$. $\mathrm{Neu}$ rosci. Res. 57 (1999), 295-303.

[156] C. Hock, K. Heese, C. Hulette, C. Rosenberg and U. Otten, Region-specific neurotrophin imbalances in Alzheimer disease: decreased levels of brain-derived neurotrophic factor and increased levels of nerve growth factor in hippocampus and cortical areas, Arch. Neurol. 57 (2000), 846-851.

[157] C. Hock, K. Heese and F. Muller-Spahn et al., Increased CSF levels of nerve growth factor in patients with Alzheimer's disease, Neurology 54 (2000), 2009-2011.

[158] C. Hock, K. Heese, F. Muller-Spahn, C. Hulette, C. Rosenberg and U. Otten, Decreased trkA neurotrophin receptor expression in the parietal cortex of patients with Alzheimer's disease, Neurosci. Lett. 241 (1998), 151-154.

[159] R.D. Hollister, W. Kisiel and B.T. Hyman, Immunohistochemical localization of tissue factor pathway inhibitor-1 (TFPI-1), a Kunitz proteinase inhibitor, in Alzheimer's disease, Brain Res 728 (1996), 13-19.

[160] R.M. Holsinger, J. Schnarr, P. Henry, V.T. Castelo and M. Fahnestock, Quantitation of BDNF mRNA in human parietal cortex by competitive reverse transcription-polymerase chain reaction: decreased levels in Alzheimer's disease, Brain Res Mol. Brain Res. 76 (2000), 347-354.

[161] M. Honda, H. Akiyama and Y. Yamada et al., Immunohistochemical evidence for a macrophage scavenger receptor in Mato cells and reactive microglia of ischemia and
Alzheimer's disease, Biochem. Biophys. Res Commun. 245 (1998), 734-740.

162] S. Honda, F. Itoh, M. Yoshimoto, S. Ohno, Y. Hinoda and K. Imai, Association between complement regulatory protein factor $\mathrm{H}$ and AM34 antigen, detected in senile plaques, $J$. Gerontol. A. Biol. Sci. Med. Sci. 55 (2000), M265-M269.

[163] R. Horuk, A.W. Martin and Z. Wang et al., Expression of chemokine receptors by subsets of neurons in the central nervous system, J. Immunol. 158 (1997), 2882-2890.

[164] M. Huell, S. Strauss, B. Volk, M. Berger and J. Bauer, Interleukin-6 is present in early stages of plaque formation and is restricted to the brains of Alzheimer's disease patients, Acta Neuropathol (Berl.) 89 (1995), 544-551.

[165] S.R. Hughes, O. Khorkova and S. Goyal et al., Alpha2macroglobulin associates with beta-amyloid peptide and prevents fibril formation, Proc. Natl. Acad. Sci. USA 95 (1998), 3275-3280.

[166] M. Hull, M. Berger, B. Volk and J. Bauer, Occurrence of interleukin- 6 in cortical plaques of Alzheimer's disease patients may precede transformation of diffuse into neuritic plaques, Ann. N. Y. Acad. Sci. 777 (1996), 205-212.

[167] M. Hull, S. Strauss, M. Berger, B. Volk and J. Bauer, The participation of interleukin-6, a stress-inducible cytokine, in the pathogenesis of Alzheimer's disease, Behav. Brain Res 78 (1996), 37-41.

[168] B.T. Hyman, K. Marzloff and P.V. Arriagada, The lack of accumulation of senile plaques or amyloid burden $n$ Alzheimer's disease suggests a dynamic balance between amyloid deposition and resolution, J. Neuropathol. Exp. Neurol. 52 (1993), 594-600.

[169] N.Y. Ip, S.H. Nye and T.G. Boulton et al., CNTF and LIF act on neuronal cells via shared signaling pathways that involve the IL-6 signal transducing receptor component gp130, Cell 69 (1992), 1121-1132.

[170] T. Ishii and S. Haga, Immuno-electron-microscopic localization of complements in amyloid fibrils of senile plaques, Acta Neuropathol. 63 (1984), 296-300.

[171] T. Ishii, S. Haga and F. Kametani, Presence of immunoglobulins and complements in the amyloid plaques in the brain of patients with Alzheimer's disease, in: Immunology and Alzheimer's disease, A. Pouplard-Bathelaix, J. Emile and Y. Christen, eds, Springer-Verlag, Berlin, 1988, pp. 17-29.

[172] K. Ishizuka, T. Kimura, R. Igata-yi, S. Katsuragi, J. Takamatsu and T. Miyakawa, Identification of monocyte chemoattractant protein-1 in senile plaques and reactive microglia of Alzheimer's disease, Psychiatry Clin. Neurosci. 51 (1997), 135-138.

[173] S. Itagaki, H. Akiyama, H. Saito and P.L. McGeer, Ultrastuctural localization of complment membrane attack complex (MAC)-like immunoreactivity in brains of patients with Alzheimer's disease, Brain Res. 645 (1994), 78-84.

[174] S. Itagaki, P.L. McGeer, H. Akiyama, S. Zhu and D. Selkoe, Relationship of microglia and astrocytes to amyloid deposits of Alzheimer disease, J. Neuroimmunol. 24 (1989), 173-182.

[175] N. Iwamoto, K. Kobayashi and K. Kosaka, The formation of prostaglandins in the postmortem cerebral cortex of Alzheimer-type dementia patients, J. Neurol 236 (1989), 8084.

[176] N. Iwamoto, E. Nishiyama, J. Ohwada and H. Arai, Demonstration of CRP immunoreactivity in brains of Alzheimer's disease: immunohistochemical study using formic acid pretreatment of tissue sections, Neurosci. Lett. 177 (1994), 2326. 
[177] N. Janabi, I. Hau and M. Tardieu, Negative feedback between prostaglandin and alpha- and beta-chemokine synthesis in human microglial cells and astrocytes, J. Immunol. 162 (1999), 1701-1706.

[178] W.A. Jefferies, M.R. Food and R. Gabathuler et al., Reactive microglia specifically associated with amyloid plaques in Alzheimer's disease brain tissue express melanotransferrin, Brain Res 712 (1996), 122-126.

[179] C. Jiang, A.T. Ting and B. Seed, PPAR-gamma agonists inhibit production of monocyte inflammatory cytokines, $\mathrm{Na}$ ture 391 (1998), 82-86.

[180] H. Jiang, D. Burdick, C.G. Glabe, C.W. Cotman and A.J. Tenner, $\beta$-Amyloid activates complement by binding to a specific region of the collagen-like domain of the $\mathrm{C} 1 \mathrm{q}$ a chain, Journal of Immunology 152 (1994), 5050-5059.

[181] T.G. Johns and C.C. Bernard, Binding of complement component $\mathrm{C} 1 \mathrm{q}$ to myelin oligodendrocyte glycoprotein:a novel mechanism for regulating CNS inflammation, Mol. Immunol. 34 (1997), 33-38

[182] S.A. Johnson, M. Lampert-Etchells, G.M. Pasinetti, I. Rozovsky and C.E. Finch, Complement mRNA in the mammalian brain: responses to Alzheimer's disease and experimental brain lesioning, Neurobiol. Aging 13 (1992), 641648.

[183] R.N. Kalaria, D.L. Cohen, D.R. Premkumar, S. Nag, J.C. LaManna and W.D. Lust, Vascular endothelial growth factor in Alzheimer's disease and experimental cerebral ischemia, Brain Res Mol. Brain Res 62 (1998), 101-105.

[184] R.N. Kalaria, T. Golde, S.N. Kroon and G. Perry, Serine protease inhibitor antithrombin III and its messenger RNA in the pathogenesis of Alzheimer's disease, Am. J. Pathol. 143 (1993), 886-893.

[185] R.N. Kalaria and S.N. Kroon, Complement inhibitor C4binding protein in amyloid deposits containing serum amyloid P in Alzheimer's disease, Biochem. Biophys. Res. Comm. 186 (1992), 461-466.

[186] J. Kalman, A. Juhasz and G. Laird et al., Serum interleukin6 levels correlate with the severity of dementia in Down syndrome and in Alzheimer's disease, Acta Neurol Scand. 96 (1997), 236-240.

[187] B. Kaltschmidt, M. Uherek, B. Volk, P.A. Baeuerle and C. Kaltschmidt, Transcription factor NF-kappaB is activated in primary neurons by amyloid beta peptides and in neurons surrounding early plaques from patients with Alzheimer disease, Proc. Natl. Acad. Sci. USA 94 (1997), 2642-2647.

[188] M.I. Kamboh, D.K. Sanghera, R.E. Ferrell and S.T. DeKosky, APOE*4-associated Alzheimer's disease risk is modified by alpha 1- antichymotrypsin polymorphism, Nat. Genet. 10 (1995), 486-488.

[189] D.E. Kang, T. Saitoh and X. Chen et al., Genetic association of the low-density lipoprotein receptor-related protein gene (LRP), an apolipoprotein E receptor, with late-onset Alzheimer's disease, Neurology 49 (1997), 56-61.

[190] N. Kawaguchi, T. Yamada and Y. Yoshiyama, Expression of interferon-alpha mRNA in human brain tissues, No. To. Shinkei. 49 (1997), 69-73.

[191] T. Kawamata, I. Tooyama, T. Yamada, D.G. Walker and P.L. McGeer, Lactotransferrin immunocytochemistry in Alzheimer and normal human brain, Am. J. Pathol. 142 (1993), 1574-1585.

[192] K.A. Kelley, L. Ho and D. Winger et al., Potentiation of excitotoxicity in transgenic mice overexpressing neuronal cyclooxygenase-2, Am. J. Pathol. 155 (1999), 995-1004.
[193] M.L. Kennard, H. Feldman, T. Yamada and W.A. Jefferies, Serum levels of the iron binding protein p97 are elevated in Alzheimer's disease, Nat. Med. 2 (1996), 1230-1235.

[194] E. Kida, N.H. Choi-Miura and K.E. Wisniewski, Deposition of apolipoproteins $\mathrm{E}$ and $\mathrm{J}$ in senile plaques is topographically determined in both Alzheimer's disease and Down's syndrome brain, Brain Res 685 (1995), 211-216.

[195] J.I. Kim, W.K. Ju and J.H. Choi et al., Expression of cytokine genes and increased nuclear factor-kappa B activity in the brains of scrapie-infected mice, Brain Res Mol. Brain Res $\mathbf{7 3}$ (1999), 17-27.

[196] H. Kimura, I. Tooyama and P.L. McGeer, Acidic FGF expression in the surroundings of senile plaques, Tohoku. J. Exp Med. 174 (1994), 279-293.

[197] R. Kisilevsky, Proteoglycans, glycosaminoglycans, amyloidenhancing factor, and amyloid deposition, J. Intern. Med. 232 (1992), 515-516.

[198] Y. Kitamura, S. Shimohama and H. Koike et al., Increased expression of cyclooxygenases and peroxisome proliferatoractivated receptor-gamma in Alzheimer's disease brains, Biochem. Biophys. Res. Commun. 254 (1999), 582-586.

[199] Y. Kitamura, S. Shimohama, T. Ota, Y. Matsuoka, Y. Nomura and T. Taniguchi, Alteration of transcription factors NF-kappaB and STAT1 in Alzheimer's disease brains, Neurosci. Lett. 237 (1997), 17-20.

[200] A. Klegeris and P.L. McGeer, $\beta$-amyloid protein enhances macrophage production of oxygen free radicals and glutamate, J. Neurosci. Res. 49 (1997), 229-235.

[201] A. Klegeris, D.G. Walker and P.L. McGeer, Activation of macrophages by Alzheimer beta amyloid peptide, Biochem. Biophys. Res Commun. 199 (1994), 984-991.

[202] N.W. Knuckey, P. Finch and D.E. Palm et al., Differential neuronal and astrocytic expression of transforming growth factor beta isoforms in rat hippocampus following transient forebrain ischemia, Brain Res. Mol. Brain Res. 40 (1996), $1-14$

[203] K.K. Kopec and R.T. Carroll, Alzheimer's beta-amyloid peptide 1-42 induces a phagocytic response in murine microglia, J. Neurochem. 71 (1998), 2123-2131.

[204] M.Z. Kounnas, R.D. Moir and G.W. Rebeck et al., LDL receptor-related protein, a multifunctional ApoE receptor, binds secreted beta-amyloid precursor protein and mediates its degradation, Cell 82 (1995), 331-340.

[205] W.J. Krall, P.M. Challita, L.S. Perlmutter, D.C. Skelton and D.B. Kohn, Cells expressing human glucocerebrosidase from a retroviral vector repopulate macrophages and central nervous system microglia after murine bone marrow transplantation, Blood 83 (1994), 2737-2748.

[206] G.W. Kreutzberg, Microglia: a sensor for pathological events in the CNS, Trends. Neurosci. 19 (1996), 312-318.

207] J. Kuby. The complement system, in: Immunology, Anonymous, (2nd ed.), W.H. Freeman and Company, New York, 1994, pp. 393-415.

[208] M. Lampert-Etchells, G.M. Pasinetti, C.E. Finch and S.A. Johnson, Regional localization of cells containing complement $\mathrm{C} 1 \mathrm{q}$ and $\mathrm{C} 4 \mathrm{mRNAs}$ in the frontal cortex during Alzheimer's disease, Neurodegeneration 2 (1993), 111-121.

[209] D.T. Laskowitz, S. Goel, E.R. Bennett and W.D. Matthew, Apolipoprotein E suppresses glial cell secretion of TNF alpha, J. Neuroimmunol. 76 (1997), 70-74.

[210] D.T. Laskowitz, W.D. Matthew and E.R. Bennett et al., Endogenous apolipoprotein E suppresses LPS-stimulated microglial nitric oxide production, Neuroreport. 9 (1998), 615618. 
[211] B.A. Lawlor, G.R. Swanwick, C. Feighery, J.B. Walsh and D. Coakley, Acute phase reactants in Alzheimer's disease, Biol. Psychiatry 39 (1996), 1051-1052.

[212] L.J. Lawson, L. Frost, J. Risbridger, S. Fearn and V.H. Perry, Quantification of the mononuclear phagocyte response to Wallerian degeneration of the optic nerve, J. Neurocytol. 23 (1994), 729-744.

[213] A. LeBlanc, Increased production of $4 \mathrm{kDa}$ amyloid beta peptide in serum deprived human primary neuron cultures: possible involvement of apoptosis, J. Neurosci. 15 (1995), 7837-7846.

[214] D.W. Lee, H.O. Sohn and H.B. Lim et al., Alteration of free radical metabolism in the brain of mice infected with scrapie agent, Free Radic. Res 30 (1999), 499-507.

[215] R.K. Lee, S. Knapp and R.J. Wurtman, Prostaglandin E2 stimulates amyloid precursor protein gene expression: inhibition by immunosuppressants, J. Neurosci. 19 (1999), 940947.

[216] S.C. Lee, M.L. Zhao, A. Hirano and D.W. Dickson, Inducible nitric oxide synthase immunoreactivity in the Alzheimer disease hippocampus: association with Hirano bodies, neurofibrillary tangles, and senile plaques, J. Neuropathol Exp Neurol 58 (1999), 1163-1169.

[217] J.M. Lehmann, J.M. Lenhard, B.B. Oliver, G.M. Ringold and S.A. Kliewer, Peroxisome proliferator-activated receptors alpha and gamma are activated by indomethacin and other nonsteroidal anti-inflammatory drugs, J. Biol. Chem. 272 (1997), 3406-3410.

[218] T. Lemberger, B. Desvergne and W. Wahli, Peroxisome proliferator-activated receptors: a nuclear receptor signaling pathway in lipid physiology, Annu. Rev. Cell Dev. Biol. 12 (1996), 335-363.

[219] B. Leveugle, G. Spik, D.P. Perl, C. Bouras, H.M. Fillit and P.R. Hof, The iron-binding protein lactotransferrin is present in pathologic lesions in a variety of neurodegenerative disorders: a comparative immunohistochemical analysis, Brain Res 650 (1994), 20-31.

[220] M. Levi-Strauss and M. Mallat, Primary cultures of murine astrocytes produce $\mathrm{C} 3$ and factor $\mathrm{B}$, two components of the alternative pathway of complement activation, J. Immunol. 139 (1987), 2361-2366.

[221] J.S. Liang, J.A. Sloane, J.M. Wells, C.R. Abraham, R.E. Fine and J.D. Sipe, Evidence for local production of acute phase response apolipoprotein serum amyloid A in Alzheimer's disease brain, Neurosci. Lett. 225 (1997), 73-76.

[222] A. Liao, R.M. Nitsch and S.M. Greenberg et al., Genetic association of an alpha2-macroglobulin (Val10001le) polymorphism and Alzheimer's disease, Hum. Mol. Genet. 7 (1998), 1953-1956.

[223] F. Licastro, M.C. Morini, E. Polazzi and L.J. Davis, Increased serum alpha 1-antichymotrypsin in patients with probable Alzheimer's disease: an acute phase reactant without the peripheral acute phase response, J. Neuroimmunol. 57 (1995), 71-75.

[224] F. Licastro, L. Parnetti and M.C. Morini et al., Acute phase reactant alpha 1-antichymotrypsin is increased in cerebrospinal fluid and serum of patients with probable Alzheimer disease, Alzheimer Dis. Assoc. Disord. 9 (1995), 112-118.

[225] F. Licastro, S. Pedrini and L. Caputo et al., Increased plasma levels of interleukin-1, interleukin-6 and alpha-1antichymotrypsin in patients with Alzheimer's disease: peripheral inflammation or signals from the brain? J. Neuroimmunol. 103 (2000), 97-102.
[226] A.M. Lidstrom, N. Bogdanovic, C. Hesse, I. Volkman, P. Davidsson and K. Blennow, Clusterin (apolipoprotein J) protein levels are increased in hippocampus and in frontal cortex in Alzheimer's disease, Exp Neurol 154 (1998), 511-521.

[227] J. Lieberman, L. Schleissner, K.H. Tachiki and A.S. Kling, Serum alpha 1-antichymotrypsin level as a marker for Alzheimer-type dementia, Neurobiol Aging 16 (1995), 747753.

[228] E. Linder, V.P. Lehto and S. Stenman, Activation of complement by cytoskeletal intermediate filaments, Nature $\mathbf{2 7 8}$ (1979), 176-178.

[229] C.F. Lippa, K.C. Flanders, E.S. Kim and S. Croul, TGF-beta receptors-I and -II immunoexpression in Alzheimer's disease: a comparison with aging and progressive supranuclear palsy, Neurobiol Aging 19 (1998), 527-533.

[230] H. Liu, R.C. Bowes, B. van de Water, C. Sillence, J.F. Nagelkerke and J.L. Stevens, Endoplasmic reticulum chaperones GRP78 and calreticulin prevent oxidative stress, Ca2 + disturbances, and cell death in renal epithelial cells, J. Biol. Chem. 272 (1997), 21751-21759.

[231] D.A. Loeffler, A.J. DeMaggio and P.L. Juneau et al., Ceruloplasmin is increased in cerebrospinal fluid in Alzheimer's disease but not Parkinson's disease, Alzheimer Dis. Assoc. Disord. 8 (1994), 190-197.

[232] D.A. Loeffler, P.A. Lewitt and P.L. Juneau et al., Increased regional brain concentrations of ceruloplasmin in neurodegenerative disorders, Brain Res 738 (1996), 265-274.

[233] V.R. Lombardi, M. Garcia and R. Cacabelos, Microglial activation induced by factor(s) contained in sera fro Alzheimerrelated ApoE genotypes, J. Neurosci. Res. 54 (1998), 539553.

[234] D. Lorton, J. Schaller, A. Lala and E. De Nardin, Chemotactic-like receptors and Abeta peptide induced responses in Alzheimer's Disease, Neurobiol Aging 21 (2000), 463-473.

[235] M.A. Lovell, W.D. Ehmann, S.M. Butler and W.R. Markesbery, Elevated thiobarbituric acid-reactive substances and antioxidant enzyme activity in the brain in Alzheimer's disease, Neurology 45 (1995), 1594-1601.

[236] M.A. Lovell, W.D. Ehmann, M.P. Mattson and W.R. Markesbery, Elevated 4-hydroxynonenal in ventricular fluid in Alzheimer's disease, Neurobiol Aging 18 (1997), 457-461.

[237] M.A. Lovell, S.P. Gabbita and W.R. Markesbery, Increased DNA oxidation and decreased levels of repair products in Alzheimer's disease ventricular CSF, J. Neurochem. 72 (1999), 771-776.

[238] M.A. Lovell, C. Xie and W.R. Markesbery, Decreased glutathione transferase activity in brain and ventricular fluid in Alzheimer's disease, Neurology 51 (1998), 1562-1566.

[239] W. Lu, R. Mi, H. Tang, S. Liu, M. Fan and L. Wang, Overexpression of c-fos mRNA in the hippocampal neurons in Alzheimer's disease, Chin. Med. J. (Engl.) 111 (1998), 3537.

[240] J. Luber-Narod and J. Rogers, Immune system associated antigens expressed by cells of the human central nervous system, Neurosci. Lett. 94 (1988), 17-22.

[241] L.F. Lue, L. Brachova, Y. Shen and J. Rogers, Modeling A $\beta$ deposition in cultures of Alzheimer's glia and hNT neurons, Neuroscience Abstracts (Abstract) 23 (1999).

[242] L.F. Lue, Y.M. Kuo and A.E. Roher et al., Soluble amyloid beta peptide concentration as a predictor of synaptic change in Alzheimer's disease, Am. J. Pathol. 155 (1999), 853-862.

[243] L.F. Lue, Y. Shen, L.B. Yang, R.E. Rydel, H. Hampel and J. Rogers, Constitutive and amyloid $\beta$ peptide-stimulated 
secretion of inflammatory mediators by Alzheimer's disease and control microglia, in: Neuroinflammation and Alzheiemer's disease, J. Rogers, ed., Birkhauser Press, Basel, 2000.

[244] W.J. Lukiw and N.G. Bazan, Cyclooxygenase 2 RNA message abundance, stability, and hypervariability in sporadic Alzheimer neocortex, J. Neurosci. Res 50 (1997), 937-945.

[245] W.J. Lukiw and N.G. Bazan, Strong nuclear factor-kappaBDNA binding parallels cyclooxygenase-2 gene transcription in aging and in sporadic Alzheimer's disease superior temporal lobe neocortex, J. Neurosci. Res 53 (1998), 583-592.

[246] J. Ma, A. Yee, H.B.J. Brewer, S. Das and H. Potter, Amyloid-associated proteins alpha 1-antichymotrypsin and apolipoprotein E promote assembly of Alzheimer betaprotein into filaments, Nature 372 (1994), 92-94.

[247] G.A. MacGibbon, P.A. Lawlor and M. Walton et al., Expression of Fos, Jun, and Krox family proteins in Alzheimer's disease, Exp Neurol 147 (1997), 316-332.

[248] I.R. Mackenzie, C. Hao and D.G. Munoz, Role of microglia in senile plaque formation, Neurobiol. Aging 16 (1995), 797 804.

[249] I.R. Mackenzie and D.G. Munoz, Nonsteroidal antiinflammatory drug use and Alzheimer-type pathology in aging, Neurology 50 (1998), 986-990.

[250] M. Majeed, K.H. Krause, R.A. Clark, Kihlstr and O. Stendahl, Localization of intracellular $\mathrm{Ca} 2+$ stores in HeLa cells during infection with Chlamydia trachomatis, J. Cell Sci. 112 (1998), 35-44.

[251] S.K. Malhotra, T.K. Shnitka and J. Elbrink, Reactive astrocytes - a review, Cytobios 61 (1990), 133-160.

[252] G.L. Mancardi, B.H. Liwnicz and T.I. Mandybur, Fibrous astrocytes in Alzheimer's disease and senile dementia of Alzheimer's type, Acta Neuropathol. (Berl.) 61 (1983), 7680.

[253] T.I. Mandybur, Cerebral amyloid angiopathy and astrocytic gliosis in Alzheimer's disease, Acta Neuropathol. (Berl.) 78 (1989), 329-331.

[254] T.I. Mandybur, I. Ormsby and F.P. Zemlan, Cerebral aging: a quantitative study of gliosis in old nude mice, Acta Neuropathol. (Berl.) 77 (1989), 507-513.

[255] D.L. Marcus, J.A. Strafaci and D.C. Miller et al., Quantitative neuronal c-fos and c-jun expression in Alzheimer's disease, Neurobiol Aging 19 (1998), 393-400.

[256] W.R. Markesbery, Oxidative stress hypothesis in Alzheimer's disease, Free Radic. Biol. Med. 23 (1997), 134-147.

[257] W.R. Markesbery and J.M. Carney, Oxidative alterations in Alzheimer's disease, Brain Pathol. 9 (1999), 133-146.

[258] W.R. Markesbery and M.A. Lovell, Four-hydroxynonenal, a product of lipid peroxidation, is increased in the brain in Alzheimer's disease, Neurobiol Aging 19 (1998), 33-36.

[259] D.R. Marshak, S.A. Pesce, L.C. Stanley and W.S. Griffin, Increased S100 beta neurotrophic activity in Alzheimer's disease temporal lobe, Neurobiol. Aging 13 (1992), 1-7.

[260] E. Masliah, M. Mallory, M. Alford, R. DeTeresa and T. Saitoh, PDGF is associated with neuronal and glial alterations of Alzheimer's disease, Neurobiol Aging 16 (1995), 549-556.

[261] E. Masliah, M. Mallory, L. Hansen, R. DeTeresa, M. Alford and R. Terry, Synaptic and neuritic alterations during the progression of Alzheimer's disease, Neurosci. Lett. 174 (1994), 67-72.

[262] E. Masliah, C.E. Westland and E.M. Rockenstein et al., Amyloid precursor proteins protect neurons of transgenic mice against acute and chronic excitotoxic injuries in vivo, $\mathrm{Neu}$ roscience 78 (1997), 135-146.
[263] L.A. Mattiace, P. Davies and D.W. Dickson, Detection of HLA-DR on microglia in the human brain is a function of both clinical and technical factors, Am. J. Pathol. 136 (1990), 1101-1114.

[264] M.P. Mattson, Central role of oxyradicals in the mechanism of amyloid beta peptide cytotoxicity, Alz. Dis. Rev. 2 (1997), $1-14$.

[265] M.P. Mattson and S.W. Barger, Roles for calcium signaling in structural plasticity and pathology in the hippocampal system, Hippocampus. 3 (1993), 73-87.

[266] M.P. Mattson, B. Cheng, A.R. Culwell, F.S. Esch, I. Lieberburg and R.E. Rydel, Evidence for excitoprotective and intraneuronal calcium-regulating roles for secreted forms of the beta-amyloid precursor protein, Neuron 10 (1993), 243-254.

[267] M.P. Mattson and W.A. Pedersen, Effects of amyloid precursor protein derivatives and oxidative stress on basal forebrain cholinergic systems in Alzheimer's disease, Int. J. Dev. Neurosci. 16 (1998), 737-753.

[268] P.C. May, M. Lampert-Etchells, S.A. Johnson, J. Poirier, J.N. Masters and C.E. Finch, Dynamics of gene expression for a hippocampal glycoprotein elevated in Alzheimer's disease and in response to experimental lesions in rat, Neuron $\mathbf{5}$ (1990), 831-839.

[269] R.D. McComb, K.A. Miller and S.D. Carson, Tissue factor antigen in senile plaques of Alzheimer's disease, Am. J. Pathol. 139 (1991), 491-494.

[270] D.R. McDonald, M.E. Bamberger, C.K. Combs and G.E. Landreth, beta-Amyloid fibrils activate parallel mitogenactivated protein kinase pathways in microglia and THP1 monocytes, J. Neurosci. 18 (1998), 4451-4460.

[271] D.R. McDonald, K.R. Brunden and G.E. Landreth, Amyloid fibrils activate tyrosine kinase-dependent signaling and superoxide production in microglia, J. Neurosci. 17 (1997), 2284-2294.

[272] P.L. McGeer, H. Akiyama, S. Itagaki and E.G. McGeer, Activation of the classical complement pathway in brain tissue of Alzheimer patients, Neurosci. Lett. 107 (1989), 341-346.

[273] P.L. McGeer, H. Akiyama, S. Itagaki and E.G. McGeer, Immune system response in Alzheimer's disease, Can. J. Neurol. Sci. 16 (1989), 516-527.

[274] P.L. McGeer, S. Itagaki, B.E. Boyes and E.G. McGeer, Reactive microglia are positive for HLA-DR in the substantia nigra of Parkinson's and Alzheimer's disease brains, Neurology 38 (1988), 1285-1291.

[275] P.L. McGeer, S. Itagaki, H. Tago and E.G. McGeer, Reactive microglia in patients with senile dementia of the Alzheimer type are positive for the histocompatibility glycoprotein HLA-DR, Neurosci. Lett. 79 (1987), 195-200.

[276] P.L. McGeer, T. Kawamata and D.G. Walker, Distribution of clusterin in Alzheimer brain tissue, Brain Res 579 (1992), 337-341.

[277] P.L. McGeer, A. Klegeris, D.G. Walker, O. Yasuhara and E.G. McGeer, Pathological proteins in senile plaques, Tohoku. J. Exp Med. 174 (1994), 269-277.

[278] P.L. McGeer and E.G. McGeer, Central nervous system immune reactions in Alzheimer's disease, in: Immune responses in the nervous system, N.J. Rothwell, ed., Bios Scientific Publishers, Manchester, UK, 1995, pp. 143-157.

[279] P.L. McGeer and E.G. McGeer, The inflammatory response system of brain: implications for therapy of Alzheimer and other neurodegenerative diseases, Brain Res. Rev. 21 (1995), 195-218.

[280] P.L. McGeer, E.G. McGeer, T. Kawamata, T. Yamada and H. Akiyama, Reactions of the immune system in chronic 
degenerative neurological diseases, Can. J. Neurol Sci. 18 (1991), 376-379.

[281] P.L. McGeer, E.G. McGeer, T. Kawamata, T. Yamada and H. Akiyama, Reactions of the immune system in chronic degenerative neurological diseases, Can. J. Neurol Sci. 18 (1991), 376-379.

[282] P.L. McGeer, D.G. Walker and H. Akiyama et al., Detection of the membrane inhibitor of reactive lysis (CD59) in diseased neurons of Alzheimer brain, Brain Res 544 (1991), 315-319.

[283] P. Mecocci, U. MacGarvey and M.F. Beal, Oxidative damage to mitochondrial DNA is increased in Alzheimer's disease, Ann. Neurol 36 (1994), 747-751.

[284] L. Minghetti, E. Polazzi, A. Nicolini, C. Creminon and G. Levi, Interferon-gamma and nitric oxide down-regulate lipopolysaccharide- induced prostanoid production in cultured rat microglial cells by inhibiting cyclooxygenase- 2 expression, J. Neurochem. 66 (1996), 1963-1970.

[285] D.L. Montgomery, Astrocytes: form, functions, and roles in disease, Vet. Pathol. 31 (1994), 145-167.

[286] T.J. Montine, M.F. Beal and M.E. Cudkowicz et al., Increased CSF F2-isoprostane concentration in probable AD, Neurology 52 (1999), 562-565.

[287] T.J. Montine, K.R. Sidell and B.C. Crews et al., Elevated CSF prostaglandin E2 levels in patients with probable AD, Neurology 53 (1999), 1495-1498.

[288] T. Morioka, T. Baba, K.L. Black and W.J. Streit, Immunophenotypic analysis of infiltrating leukocytes and microglia in an experimental rat glioma, Acta Neuropathol. (Berl.) 83 (1992), 590-597.

[289] T. Morioka, A.N. Kalehua and W.J. Streit, Characterization of microglial reaction after middle cerebral artery occlusion in rat brain, J. Comp. Neurol. 327 (1993), 123-132.

[290] R.E. Mrak, J.G. Sheng and W.S. Griffin, Correlation of astrocytic S100 beta expression with dystrophic neurites in amyloid plaques of Alzheimer's disease, J. Neuropathol. Exp. Neurol. 55 (1996), 273-279.

[291] L. Mucke, C.R. Abraham and M.D. Ruppe et al., Protection against HIV-1 gp120-induced brain damage by neuronal expression of human amyloid precursor protein, J. Exp. Med. 181 (1995), 1551-1556.

[292] L. Mucke, E. Masliah and W.B. Johnson et al., Synaptotrophic effects of human amyloid beta protein precursors in the cortex of transgenic mice, Brain Res. 666 (1994), 151167.

[293] E.J. Mufson, J.M. Conner and J.H. Kordower, Nerve growth factor in Alzheimer's disease: defective retrograde transport to nucleus basalis, Neuroreport. 6 (1995), 1063-1066.

[294] E.J. Mufson, N. Lavine, S. Jaffar, J.H. Kordower, R. Quirion and H.U. Saragovi, Reduction in p140-TrkA receptor protein within the nucleus basalis and cortex in Alzheimer's disease, Exp Neurol 146 (1997), 91-103.

[295] E.J. Mufson, J.M. Li, T. Sobreviela and J.H. Kordower, Decreased trkA gene expression within basal forebrain neurons in Alzheimer's disease, Neuroreport. 8 (1996), 25-29.

[296] H.J. Muller-Eberhard, Molecular organization and function of the complement system, Annu. Rev. Biochem. 57 (1988), 321-347.

[297] G. Multhaup, T. Ruppert and A. Schlicksupp et al., Reactive oxygen species and Alzheimer's disease, Biochem. Pharmacol. 54 (1997), 533-539.

[298] Multiple, Multiple Titles, Neurobiol. Aging 17 (1996).

[299] M.A. Munoz-Fernandez and M. Fresno, The role of tumour necrosis factor, interleukin 6 , interferon-gamma and in- ducible nitric oxide synthase in the development and pathology of the nervous system, Prog. Neurobiol 56 (1998), 307340 .

[300] M.G. Murer, F. Boissiere and Q. Yan et al., An immunohistochemical study of the distribution of brain-derived neurotrophic factor in the adult human brain, with particular reference to Alzheimer's disease, Neuroscience 88 (1999), 1015-1032.

[301] P.G. Murphy, L.S. Borthwick, R.S. Johnston, G. Kuchel and P.M. Richardson, Nature of the retrograde signal from injured nerves that induces interleukin-6 mRNA in neurons, $J$. Neurosci. 19 (1999), 3791-3800.

[302] S. Nakamura, K. Arima and S. Haga et al., Fibroblast growth factor (FGF)-9 immunoreactivity in senile plaques, Brain Res 814 (1998), 222-225.

[303] M. Nakayama, K. Uchimura and R.L. Zhu et al., Cyclooxygenase-2 inhibition prevents delayed death of CA1 hippocampal neurons following global ischemia, Proc. Natl. Acad. Sci. USA 95 (1998), 10954-10959.

[304] M. Narisawa-Saito, K. Wakabayashi, S. Tsuji, H. Takahashi and H. Nawa, Regional specificity of alterations in NGF, BDNF and NT-3 levels in Alzheimer's disease, Neuroreport. 7 (1996), 2925-2928.

[305] M. Narita, D.M. Holtzman, A.L. Schwartz and G. Bu, Alpha2-macroglobulin complexes with and mediates the endocytosis of beta-amyloid peptide via cell surface lowdensity lipoprotein receptor- related protein, J. Neurochem. 69 (1997), 1904-1911.

[306] S. Nataf, P.F. Stahel, N. Davoust and S.R. Barnum, Complement anaphylatoxin receptors on neurons: new tricks for old receptors? Trends. Neurosci. 22 (1999), 397-402.

[307] Neuroinflammation Working Group, H. Akiyama and S. Barger et al., Inflammation and Alzheimer's disease, Neurobiol Aging 21 (2000), 383-421.

308] T. Nishimura, H. Akiyama and S. Yonehara et al., Fas antigen expression in brains of patients with Alzheimer-type dementia, Brain Res 695 (1995), 137-145.

[309] S. Nogawa, F. Zhang, M.E. Ross and C. Iadecola, Cyclooxygenase- 2 gene expression in neurons contributes to ischemic brain damage, J. Neurosci. 17 (1997), 2746-2755.

[310] J. Nourooz-Zadeh, E.H. Liu, B. Yhlen, E.E. Anggard and B. Halliwell, F4-isoprostanes as specific marker of docosahexaenoic acid peroxidation in Alzheimer's disease, J. Neurochem. 72 (1999), 734-740.

[311] M.K. O'Banion, Cyclooxygenase-2: molecular biology, pharmacology, and neurobiology, Crit. Rev. Neurobiol. 13 (1999), 45-82.

[312] M.K. O'Banion, J.W. Chang and P.D. Coleman, Decreased expression of prostaglandin $\mathrm{G} / \mathrm{H}$ synthase-2 (PGHS-2) in Alzheimer's disease brain, Adv. Exp Med. Biol. 407 (1997), 171-177.

[313] M.K. O’Banion, J.C. Miller, J.W. Chang, M.D. Kaplan and P.D. Coleman, Interleukin-1 beta induces prostaglandin $\mathrm{G} / \mathrm{H}$ synthase-2 (cyclooxygenase- 2) in primary murine astrocyte cultures, J. Neurochem. 66 (1996), 2532-2540.

[314] A. Oka and S. Takashima, Induction of cyclo-oxygenase 2 in brains of patients with Down's syndrome and dementia of Alzheimer type: specific localization in affected neurones and axons, Neuroreport. 8 (1997), 1161-1164.

[315] J.D. Oliver, F.J. Van der Wal, N.J. Bulleid and S. High, Interaction of the thiol-dependent reductase ERp57 with nascent glycoproteins, Science 275 (1997), 86-88.

[316] O. Orzylowska, B. Oderfeld-Nowak, M. Zaremba, S. Januszewski and M. Mossakowski, Prolonged and concomi- 
tant induction of astroglial immunoreactivity of interleukin1 beta and interleukin-6 in the rat hippocampus after transient global ischemia, Neurosci. Lett. 263 (1999), 72-76.

[317] A.M. Palmer and M.A. Burns, Selective increase in lipid peroxidation in the inferior temporal cortex in Alzheimer's disease, Brain Res 645 (1994), 338-342.

[318] M.K. Pangburn and H.J. Muller-Eberhard, The alternative pathway of complement, Springer Semin. Immunopathol. 7 (1984), 163-192.

[319] A. Papassotiropoulos, M. Bagli and F. Jessen et al., A genetic variation of the inflammatory cytokine interleukin-6 delays the initial onset and reduces the risk for sporadic Alzheimer's disease, Ann. Neurol. 45 (1999), 666-668.

[320] D.M. Paresce, H. Chung and F.R. Maxfield, Slow degradation of aggregates of the Alzheimer's disease amyloid beta- protein by microglial cells, J. Biol. Chem. 272 (1997), 2939029397.

[321] G.M. Pasinetti, Cyclooxygenase and inflammation in Alzheimer's disease: experimental approaches and clinical interventions, J. Neurosci. Res. 54 (1998), 1-6.

[322] G.M. Pasinetti and P.S. Aisen, Cyclooxygenase-2 expression is increased in frontal cortex of Alzheimer's disease brain, Neuroscience 87 (1998), 319-324.

[323] G.M. Pasinetti, S.A. Johnson and I. Rozovsky et al., Complement $\mathrm{C} 1 \mathrm{qB}$ and $\mathrm{C} 4 \mathrm{mRNAs}$ responses to lesioning in rat brain, Exp. Neurol. 118 (1992), 117-125.

[324] N.S. Peress and E. Perillo, Differential expression of TGFbeta 1, 2 and 3 isotypes in Alzheimer's disease: a comparative immunohistochemical study with cerebral infarction, aged human and mouse control brains, J. Neuropathol. Exp. Neurol. 54 (1995), 802-811.

[325] V.H. Perry, M.D. Bell and D.C. Anthony, Unique aspects of inflammation in the central nervous system, in: Inflammatory cells and mediators in CNS diseases, R.R. Ruffolo, G.Z. Feuerstain, A.J. Hunter, G. Poste and B.W. Metcalf, eds, Harwood Academeic Publishers, Canada, 1999, pp. 21-38.

[326] V.H. Perry, D.A. Hume and S. Gordon, Immunohistochemical localization of macrophages and microglia in the adult and developing mouse brain, Neuroscience 15 (1985), 313326.

[327] H.S. Phillips, J.M. Hains, M. Armanini, G.R. Laramee, S.A. Johnson and J.W. Winslow, BDNF mRNA is decreased in the hippocampus of individuals with Alzheimer's disease, Neuron 7 (1991), 695-702.

[328] H.S. Phillips, J.M. Hains, M. Armanini, G.R. Laramee, S.A. Johnson and J.W. Winslow, BDNF mRNA is decreased in the hippocampus of individuals with Alzheimer's disease, Neuron 7 (1991), 695-702.

[329] D. Piani, M. Spranger, K. Frei, A. Schaffner and A. Fontana, Macrophage-induced cytotoxicity of N-methyl-D-aspartate receptor positive neurons involves excitatory amino acids rather than reactive oxygen intermediates and cytokines, Eur. J. Immunol. 22 (1992), 2429-2436.

[330] C.R. Plata-Salaman, Cytokine-induced anorexia. Behavioral, cellular, and molecular mechanisms, Ann. N. Y. Acad. Sci. 856 (1998), 160-170

[331] C.R. Plata-Salaman, S.E. Ilyin and D. Gayle, Brain cytokine mRNAs in anorectic rats bearing prostate adenocarcinoma tumor cells, Am. J. Physiol. 275 (1998), R566-R573.

[332] W. Poller, J.P. Faber, G. Klobeck and K. Olek, Cloning of the human alpha 2-macroglobulin gene and detection of mutations in two functional domains: the bait region and the thiolester site, Hum. Genet. 88 (1992), 313-319.
[333] D. Pratico, L.V. MY, J.Q. Trojanowski, J. Rokach and G.A. Fitzgerald, Increased F2-isoprostanes in Alzheimer's disease: evidence for enhanced lipid peroxidation in vivo, FASEB J. 12 (1998), 1777-1783.

[334] A. Probst, J. Ulrich and P.U. Heitz, Senile dementia of Alzheimer type: astroglial reaction to extracellular neurofibrillary tangles in the hippocampus. An immunocytochemical and electron-microscopic study, Acta Neuropathol. (Berl.) 57 (1982), 75-79.

[335] G.W. Rebeck, S.D. Harr, D.K. Strickland and B.T. Hyman, Multiple, diverse senile plaque-associated proteins are ligands of an apolipoprotein E receptor, the alpha 2macroglobulin receptor/low- density-lipoprotein receptorrelated protein, Ann. Neurol. 37 (1995), 211-217.

[336] G.W. Rebeck, J.S. Reiter, D.K. Strickland and B.T. Hyman, Apolipoprotein E in sporadic Alzheimer's disease: allelic variation and receptor interactions, Neuron 11 (1993), 575580.

337] W.F. Reynolds, J. Rhees and D. Maciejewski et al., Myeloperoxidase polymorphism is associated with gender specific risk for Alzheimer's disease, Exp. Neurol. 155 (1999), 31-41.

[338] M. Ricote, A.C. Li, T.M. Willson, C.J. Kelly and C.K. Glass, The peroxisome proliferator-activated receptor-gamma is a negative regulator of macrophage activation, Nature 391 (1998), 79-82.

[339] J. Rogers, N.R. Cooper and S. Webster et al., Complement activation by beta-amyloid in Alzheimer disease, Proc. Natl. Acad. Sci. USA 89 (1992), 10016-10020.

[340] J. Rogers and W.S.T. Griffin, Inflammatory mechanisms of Alzheimer's disease, in: Neuroinflammation: Mechanisms and Management, P.L. Wood, ed., 1998, pp. 177-193.

[341] J. Rogers, J. Luber-Narod, S.D. Styren and W.H. Civin, Expression of immune system-associated antigens by cells of the human central nervous system: relationship to the pathology of Alzheimer's disease, Neurobiol. Aging 9 (1988), 339349.

[342] J. Rogers, L.F. Lue and L.B. Yang et al., Complement activation by neurofibrillary tangles in Alzheimer's disease, Proc. Natl. Acad. Sci. USA (2000).

[343] J. Rogers and S. O'Barr, Inflammatory mediators in Alzheimer's disease, in: Molecular approaches to Alzheimer's Disease, R.E. Tanzi and W. Wasco, eds, Humana Press, Totawa, NJ, 1996, pp. 177-197.

[344] D.E. Rosenblatt, C. Geula and M.M. Mesulam, Protease nexin I immunostaining in Alzheimer's disease, Ann. Neurol 26 (1989), 628-634.

[345] B.M. Ross, A. Moszczynska, J. Erlich and S.J. Kish, Phospholipid-metabolizing enzymes in Alzheimer's disease: increased lysophospholipid acyltransferase activity and decreased phospholipase A2 activity, J. Neurochem. 70 (1998), 786-793.

[346] J.M. Rozemuller, J.J. Abbink, A.M. Kamp, F.C. Stam, C.E. Hack and P. Eikelenboom, Distribution pattern and functional state of alpha 1-antichymotrypsin in plaques and vascular amyloid in Alzheimer's disease. A immunohistochemical study with monoclonal antibodies against native and inactivated alpha 1-antichymotrypsin, Acta Neuropathol. (Berl.) 82 (1991), 200-207.

[347] J.M. Rozemuller, P. Eikelenboom, S.T. Pals and F.C. Stam, Microglial cells around amyloid plaques in Alzheimer's disease express leucocyte adhesion molecules of the LFA-1 family, Neurosci. Lett. 101 (1989), 288-292.

[348] J.M. Rozemuller, P. Eikelenboom, F.C. Stam, K. Beyreuther and C.L. Masters, A4 protein in Alzheimer's disease: pri- 
mary and secondary cellular events in extracellular amyloid deposition, J. Neuropathol. Exp. Neurol. 48 (1989), 674-691.

[349] J.M. Rozemuller, F.C. Stam and P. Eikelenboom, Acute phase proteins are present in amorphous plaques in the cerebral but not in the cerebellar cortex of patients with Alzheimer's disease, Neurosci. Lett. 119 (1990), 75-78.

[350] A. Salehi, J. Verhaagen, P.A. Dijkhuizen and D.F. Swaab, Colocalization of high-affinity neurotrophin receptors in nucleus basalis of Meynert neurons and their differential reduction in Alzheimer's disease, Neuroscience 75 (1996), 373-387.

[351] D. Salvemini, Regulation of cyclooxygenase enzymes by niric oxide, Cell Mol. Life Sci. 53 (1997), 576-582.

[352] D.L. Samudralwar, C.C. Diprete, B.F. Ni, W.D. Ehmann and W.R. Markesbery, Elemental imbalances in the olfactory pathway in Alzheimer's disease, J. Neurol Sci. 130 (1995), $139-145$.

[353] A. Sasaki, H. Yamaguchi, A. Ogawa, S. Sugihara and Y. Nakazato, Microglial activation in early stages of amyloid beta protein deposition, Acta Neuropathol. (Berl.) 94 (1997), 316-322.

[354] R. Schechter, S.H. Yen and R.D. Terry, Fibrous Astrocytes in senile dementia of the Alzheimer type, J. Neuropathol. Exp Neurol 40 (1981), 95-101.

[355] D. Schenk, R. Barbour and W. Dunn et al., Immunization with amyloid-beta attenuates Alzheimer-disease-like pathology in the PDAPP mouse, Nature 400 (1999), 173-177.

[356] A.H. Schmaier, L.D. Dahl and A.J. Rozemuller et al., Protease nexin-2/amyloid beta protein precursor. A tight-binding inhibitor of coagulation factor IXa, J. Clin. Invest. 92 (1993), 2540-2545.

[357] C. Schwab, J.C. Steele, E.G. McGeer and P.L. McGeer, Amyloid $\mathrm{P}$ immunoreactivity precedes $\mathrm{C} 4 \mathrm{~d}$ deposition on extracellular neurofibrillary tangles, Acta Neuropathol (Berl.) 93 (1997), 87-92.

[358] S.A. Scott, S.A. Johnson, C. Zarow and L.S. Perlmutter, Inability to detect $\beta$-amyloid protein precursor mRNA in Alzheimer plaque-associated microglia, Exp. Neurol. 121 (1993), 113-118.

[359] S.A. Scott, E.J. Mufson, J.A. Weingartner, K.A. Skau and K.A. Crutcher, Nerve growth factor in Alzheimer's disease: increased levels throughout the brain coupled with declines in nucleus basalis, J. Neurosci. 15 (1995), 6213-6221.

[360] D. Senitz and R. Goertchen, [Changes of orbitofrontal astroglia in senile dementia] Uber Astrozytenveranderungen in der orbitofrontalen Hirnrinde bei seniler Demenz, Zentralbl. Allg. Pathol. 122 (1978), 515-521.

[361] L.M. Shaffer, M.D. Dority, R. Gupta-Bansal, R.C. Frederickson, S.G. Younkin and K.R. Brunden, Amyloid beta protein $(\mathrm{A} \beta)$ removal by neuroglial cells in culture, Neurobiol. Aging 16 (1995), 737-745.

[362] M. Shago, G. Flock and C.Y. Leung-Hagesteijn et al., Modulation of the retinoic acid and retinoid $\mathrm{X}$ receptor signaling pathways in P19 embryonal carcinoma cells by calreticulin, Exp. Cell Res. 230 (1997), 50-60.

[363] Y. Shen, R. Li, E.G. McGeer and P.L. McGeer, Neuronal expression of mRNAs for complement proteins of the classical pathway in Alzheimer brain, Brain Res. 769 (1997), 391-395.

[364] J.G. Sheng, W.S. Griffin, M.C. Royston and R.E. Mrak, Distribution of interleukin-1-immunoreactive microglia in cerebral cortical layers: implications for neuritic plaque formation in Alzheimer's disease, Neuropathol Appl. Neurobiol 24 (1998), 278-283.
[365] J.G. Sheng, R.E. Mrak and W.S. Griffin, S100 beta protein expression in Alzheimer disease: potential role in the pathogenesis of neuritic plaques, J. Neurosci. Res. 39 (1994), 398404.

[366] J.G. Sheng, R.E. Mrak and W.S. Griffin, Microglial interleukin-1 alpha expression in brain regions in Alzheimer's disease: correlation with neuritic plaque distribution, Neuropathol. Appl. Neurobiol 21 (1995), 290-301.

[367] J.G. Sheng, R.E. Mrak and W.S. Griffin, Glial-neuronal interactions in Alzheimer disease: progressive association of IL1alpha + microglia and S100beta+ astrocytes with neurofibrillary tangle stages, J. Neuropathol. Exp Neurol 56 (1997), 285-290.

[368] J.G. Sheng, R.E. Mrak, C.R. Rovnaghi, E. Kozlowska, L.J. Van Eldik and W.S. Griffin, Human brain S100 beta and S100 beta mRNA expression increases with age: pathogenic implications for Alzheimer's disease, Neurobiol. Aging 17 (1996), 359-363.

[369] K. Shigematsu, P.L. McGeer, D.G. Walker, T. Ishii and E.G. McGeer, Reactive microglia/macrophages phagocytose amyloid precursor protein produced by neurons following neural damage, J. Neurosci. Res. 31 (1992), 443-453.

[370] T. Shirahama, K. Miura, S.T. Ju, R. Kisilevsky, E. Gruys and A.S. Cohen, Amyloid enhancing factor-loaded macrophages in amyloid fibril formation, Lab. Invest. 62 (1990), 61-68.

[371] H. Shirai, T. Murakami, Y. Yamada, T. Doi, T. Hamakubo and T. Kodama, Structure and function of type I and II macrophage scavenger receptors, Mech. Ageing Dev. 111 (1999), 107-121.

[372] V.K. Singh, Circulating cytokines in Alzheimer's disease, $J$. Psychiatr. Res. 31 (1997), 657-660.

[373] V.L. Smith-Swintosky, L.C. Pettigrew, S.D. Craddock, A.R. Culwell, R.E. Rydel and M.P. Mattson, Secreted forms of beta-amyloid precursor protein protect against ischemic brain injury, J. Neurochem. 63 (1994), 781-784.

[374] M.A. Smith, H.P. Richey, L.M. Sayre, J.S. Beckman and G. Perry, Widespread peroxynitrite-mediated damage in Alzheimer's disease, J. Neurosci. 17 (1997), 2653-2657.

[375] R.P. Smith, D.A. Higuchi and G.J.J. Broze, Platelet coagulation factor XIa-inhibitor, a form of Alzheimer amyloid precursor protein, Science 248 (1990), 1126-1128.

[376] A.D. Snow, H. Mar and D. Nochlin et al., The presence of heparan sulfate proteoglycans in the neuritic plaques and congophilic angiopathy in Alzheimer's disease, Am. J. Pathol. 133 (1988), 456-463.

[377] V. Soontornniyomkij, G. Wang, C.A. Pittman, R.L. Hamilton, C.A. Wiley and C.L. Achim, Absence of brain-derived neurotrophic factor and trkB receptor immunoreactivity in glia of Alzheimer's disease, Acta Neuropathol (Berl.) 98 (1999), 345-348.

[378] L. Sottrup-Jensen, Alpha-macroglobulins: structure, shape, and mechanism of proteinase complex formation, J. Biol. Chem. 264 (1989), 11539-11542.

[379] K. Spiegel, M.R. Emmerling and S.R. Barnum, Acute phase proteins: strategies for inhibition of complement activation in the treatment of neurodegenerative disorders, in: AnonymousHumana Press, Totowa, NJ, 1999, pp. 129-176.

[380] A.K. Stalder, M.J. Carson and A. Pagenstecher et al., Lateonset chronic inflammatory encephalopathy in immunecompetent and severe combined immune-deficient (SCID) mice with astrocyte-targeted expression of tumor necrosis factor, Am. J. Pathol. 153 (1998), 767-783.

[381] M. Stalder, A. Phinney, A. Probst, B. Sommer, M. Staufenbiel and M. Jucker, Association of microglia with amyloid 
plaques in brains of APP23 transgenic mice, Am. J. Pathol. 154 (1999), 1673-1684.

[382] D.T. Stephenson, C.A. Lemere, D.J. Selkoe and J.A. Clemens, Cytosolic phospholipase A2 (cPLA2) immunoreactivity is elevated in Alzheimer's disease brain, Neurobiol Dis. 3 (1996), 51-63.

[383] E.G. Stopa, A.M. Gonzalez and R. Chorsky et al., Basic fibroblast growth factor in Alzheimer's disease, Biochem. Biophys. Res Commun. 171 (1990), 690-696.

[384] S. Strauss, J. Bauer, U. Ganter, U. Jonas, M. Berger and B. Volk, Detection of interleukin-6 and alpha 2-macroglobulin immunoreactivity in cortex and hippocampus of Alzheimer's disease patients, Lab. Invest. 66 (1992), 223-230.

[385] W.J. Streit and D.L. Sparks, Activation of microglia in the brains of humans with heart disease and hypercholesterolemic rabbits, J. Mol. Med. 75 (1997), 130-138.

[386] W.J. Streit, S.A. Walter and N.A. Pennell, Reactive microgliosis, Prog. Neurobiol. 57 (1999), 563-581.

[387] W.J. Strittmatter, K.H. Weisgraber and D.Y. Huang et al., Binding of human apolipoprotein $\mathrm{E}$ to synthetic amyloid beta peptide: isoform-specific effects and implications for late-onset Alzheimer disease, Proc. Natl. Acad. Sci. USA 90 (1993), 8098-8102.

[388] R. Strohmeyer, Y. Shen and J. Rogers, Detection of complement alternative pathway mRNA and proteins in Alzheimer's disease brain, Mol. Brain Res. (2000), in press.

[389] S.D. Styren, W.H. Civin and J. Rogers, Molecular, cellular, and pathologic characterization of HLA-DR immunoreactivity in normal elderly and Alzheimer's disease brain, Exp. Neurol. 110 (1990), 93-104.

[390] S.D. Styren, E.J. Mufson, G.C. Styren, W.H. Civin and J. Rogers, Epidermal growth factor receptor expression in demented and aged human brain, Brain Res 512 (1990), 347352.

[391] J.H. Su, G. Deng and C.W. Cotman, Neuronal DNA damage precedes tangle formation and is associated with upregulation of nitrotyrosine in Alzheimer's disease brain, Brain Res 774 (1997), 193-199.

[392] K.V. Subbarao, J.S. Richardson and L.C. Ang, Autopsy samples of Alzheimer's cortex show increased peroxidation in vitro, J. Neurochem. 55 (1990), 342-345.

[393] R. Sutton, M.E. Keohane, S.R. VanderBerg and S.L. Gonias, Plasminogen activator inhibitor-1 in the cerebrospinal fluid as an index of neurological disease, Blood Coagul. Fibrinolysis 5 (1994), 167-171.

[394] S. Suzuki, K. Tanaka, E. Nagata, D. Ito, T. Dembo and Y. Fukuuchi, Cerebral neurons express interleukin-6 after transient forebrain ischemia in gerbils, Neurosci. Lett. 262 (1999), 117-120.

[395] K. Takami, A. Matsuo, K. Terai, D.G. Walker, E.G. McGeer and P.L. McGeer, Fibroblast growth factor receptor-1 expression in the cortex and hippocampus in Alzheimer's disease, Brain Res 802 (1998), 89-97.

[396] A. Takeda, T. Yasuda and T. Miyata et al., Advanced glycation end products co-localized with astrocytes and microglial cells in Alzheimer's disease brain, Acta Neuropathol. (Berl.) 95 (1998), 555-558.

[397] E. Tarkowski, K. Blennow, A. Wallin and A. Tarkowski, Intracerebral production of tumor necrosis factor-alpha, a local neuroprotective agent, in Alzheimer disease and vascular dementia, J. Clin. Immunol. 19 (1999), 223-230.

[398] E. Tarkowski, A.M. Liljeroth and A. Nilsson et al., TNF gene polymorphism and its relation to intracerebral production of
TNFalpha and TNFbeta in AD, Neurology 54 (2000), 20772081.

[399] J.L. Tchelingerian, L. Vignais and C. Jacque, TNF alpha gene expression is induced in neurones after a hippocampal lesion, Neuroreport. 5 (1994), 585-588.

[400] S.J. Teipel, H. Hampel and G.E. Alexander et al., Dissociation between corpus callosum atrophy and white matter pathology in Alzheimer's disease, Neurology 51 (1998), 1381-1385.

[401] K. Terai, A. Matsuo and P.L. McGeer, Enhancement of immunoreactivity for NF-kappa B in the hippocampal formation and cerebral cortex of Alzheimer's disease, Brain Res 735 (1996), 159-168.

[402] K. Terai, D.G. Walker, E.G. McGeer and P.L. McGeer, Neurons express proteins of the classical complement pathway in Alzheimer disease, Brain Res 769 (1997), 385-390.

[403] R.D. Terry, E. Masliah and D.P. Salmon et al., Physical basis of cognitive alterations in Alzheimer's disease: synapse loss is the major correlate of cognitive impairment, Ann. Neurol 30 (1991), 572-580.

[404] A. Tham, A. Nordberg, F.E. Grissom, C. Carlsson-Skwirut, M. Viitanen and V.R. Sara, Insulin-like growth factors and insulin-like growth factor binding proteins in cerebrospinal fluid and serum of patients with dementia of the Alzheimer type, J. Neural Transm. Park. Dis. Dement. Sect. 5 (1993), 165-176.

[405] C.M. Thompson, W.R. Markesbery, W.D. Ehmann, Y.X. Mao and D.E. Vance, Regional brain trace-element studies in Alzheimer's disease, Neurotoxicology 9 (1988), 1-7.

[406] V. Thorns and E. Masliah, Evidence for neuroprotective effects of acidic fibroblast growth factor in Alzheimer disease, J. Neuropathol Exp Neurol 58 (1999), 296-306.

[407] G. Tocco, J. Freire-Moar, S.S. Schreiber, S.H. Sakhi, P.S. Aisen and G.M. Pasinetti, Maturational regulation and regional induction of cyclooxygenase-2 in rat brain: implications for Alzheimer's disease, Exp. Neurol. 144 (1997), 339-349.

[408] I. Tooyama, T. Kawamata, H. Akiyama, S.K. Moestrup, J. Gliemann and P.L. McGeer, Immunohistochemical study of alpha 2 macroglobulin receptor in Alzheimer and control postmortem human brain, Mol. Chem. Neuropathol. 18 (1993), 153-160.

[409] I. Tooyama, H. Kimura, H. Akiyama and P.L. McGeer, Reactive microglia express class I and class II major histocompatibility complex antigens in Alzheimer's disease, Brain Res 523 (1990), 273-280.

[410] J.M. Tuohy, J.J. Schultz, L. Brachova, L.F. Lue and J. Rogers, Evidence of increased levels of $\mathrm{C} 4$ binding protein in Alzheimer's disease, Neurosci. Abstr. (Abstract) 19 (1993).

[411] L.J. van der Laan, S.R. Ruuls, K.S. Weber, I.J. Lodder, E.A. Dopp and C.D. Dijkstra, Macrophage phagocytosis of myelin in vitro determined by flow cytometry: phagocytosis is mediated by CR3 and induces production of tumor necrosis factor-alpha and nitric oxide, J. Neuroimmunol. 70 (1996), $145-152$.

[412] E.A. van der Wal, F. Gomez-Pinilla and C.W. Cotman, Transforming growth factor-beta 1 is in plaques in Alzheimer and Down pathologies, Neuroreport. 4 (1993), 69-72.

[413] L.J. Van Eldik and W.S. Griffin, S100 beta expression in Alzheimer's disease: relation to neuropathology in brain regions, Biochim. Biophys. Acta 1223 (1994), 398-403.

[414] D. Van Gool, B. De Strooper, F. Van Leuven, E. Triau and R. Dom, alpha 2-Macroglobulin expression in neuritic-type 
plaques in patients with Alzheimer's disease, Neurobiol Aging 14 (1993), 233-237.

[415] F.L. Van Muiswinkel, C. DeGroot, J. Rozemuller-Kwakkel and P. Eikelenboom, Enhanced expression of microglial NADPH-oxidase (p22-phox) in Alzheimer's Disease, in: K. Iqbal, D. Swaab, B. Winblad and H.M. Wisniewski, eds, John Wiley \& Sons, London, UK, 1999, pp. 451-456.

[416] F.L. Van Muiswinkel, S.F. Raupp and N.M. de Vos et al., The amino-terminus of the amyloid-beta protein is critical for the cellular binding and consequent activation of the respiratory burst of human macrophages, J. Neuroimmunol. 96 (1999), 121-130.

[417] F.L. Van Muiswinkel, R. Veerhuis and P. Eikelenboom, Amyloid beta protein primes cultured rat microglial cells for an enhanced phorbol 12-myristate 13-acetate-induced respiratory burst activity, J. Neurochem. 66 (1996), 2468-2476.

[418] P.J. Vaughan, J. Su, C.W. Cotman and D.D. Cunningham, Protease nexin-1, a potent thrombin inhibitor, is reduced around cerebral blood vessels in Alzheimer's disease, Brain Res 668 (1994), 160-170.

[419] R. Veerhuis, I. Janssen, J.J. Hoozemans, C.J. De Groot, C.E. Hack and P. Eikelenboom, Complement C1-inhibitor expression in Alzheimer's disease, Acta Neuropathol. 96 (1998), 287-296.

[420] R. Veerhuis, I. Janssen, C.J. De Groot, F.L. Van Muiswinkel, C.E. Hack and P. Eikelenboom, Cytokines associated with amyloid plaques in Alzheimer's disease brain stimulate human glial and neuronal cell cultures to secrete early complement proteins, but not C1-inhibitor, Exp Neurol 160 (1999), 289-299.

[421] R. Veerhuis, I. Janssen, C.E. Hack and P. Eikelenboom, Early complement components in Alzheimer's disease brains, Acta Neuropathol (Berl.) 91 (1996), 53-60.

[422] R. Veerhuis, V. d. van, I. Janssen, S.S. Zhan, W.E. Van Nostrand and P. Eikelenboom, Complement activation in amyloid plaques in Alzheimer's disease brains does not proceed further than C3, Virchows Arch. 426 (1995), 603-610.

[423] M.M. Verbeek, I. Otte-Holler, R. Veerhuis, D.J. Ruiter and R.M. de Waal, Distribution of A beta-associated proteins in cerebrovascular amyloid of Alzheimer's disease, Acta Neuropathol (Berl.) 96 (1998), 628-636.

[424] M.M. Verbeek, I. Otte-Holler, J.R. Westphal, P. Wesseling, D.J. Ruiter and R.M. de Waal, Accumulation of intercellular adhesion molecule- 1 in senile plaques in brain tissue of patients with Alzheimer's disease, Am. J. Pathol. 144 (1994), 104-116.

[425] S.L. Wagner, J.W. Geddes and C.W. Cotman et al., Protease nexin-1, an antithrombin with neurite outgrowth activity, is reduced in Alzheimer disease, Proc. Natl. Acad. Sci. USA 86 (1989), 8284-8288.

[426] D.G. Walker, Expression and regulation of complement C1q by human THP-1-derived macrophages, Mol. Chem. Neuropathol. 34 (1998), 197-218.

[427] D.G. Walker, Inflammatory markers in chronic neurodegenerative disorders with emphasis on Alzheiemer's disease, in: Neuroinflammation: Mechanisms and Management, P.L. Wood, ed., Humana Press Inc., Totowa, NJ, 1998, pp. 61-90.

[428] D.G. Walker, S.U. Kim and P.L. McGeer, Complement and cytokine gene expression in cultured microglia derived from postmortem human brains, J. Neurosci. Res. 40 (1995), 478493.

[429] D.G. Walker, S.U. Kim and P.L. McGeer, Expression of complement $\mathrm{C} 4$ and $\mathrm{C} 9$ genes by human astrocytes, Brain Res. 809 (1998), 31-38.
[430] D.G. Walker and P.L. McGeer, Complement gene expression in human brain: comparison between normal and Alzheimer disease cases, Brain Res Mol. Brain Res 14 (1992), 109-116.

[431] D.G. Walker, O. Yasuhara, P.A. Patston, E.G. McGeer and P.L. McGeer, Complement $\mathrm{C} 1$ inhibitor is produced by brain tissue and is cleaved in Alzheimer disease, Brain Res 675 (1995), 75-82.

[432] M.D. Watson, A.E. Roher, K.S. Kim, K. Spiegel and M.R. Emmerling, Complement interactions with amyloid- $\beta$ 1-42: a nidus for inflammation in AD brains, Amyloid 4 (1997), $147-156$.

[433] S. Webster, B. Bradt, J. Rogers and N. Cooper, Aggregation state-dependent activation of the classical complement pathway by the amyloid beta peptide, J. Neurochem. 69 (1997), 388-398.

[434] S. Webster, C. Glabe and J. Rogers, Multivalent binding of complement protein $\mathrm{C} 1 \mathrm{Q}$ to the amyloid beta- peptide (A beta) promotes the nucleation phase of A beta aggregation, Biochem. Biophys. Res. Commun. 217 (1995), 869-875.

[435] S. Webster, L.F. Lue and L. Brachova et al., Molecular and cellular characterization of the membrane attack complex, C5b-9, in Alzheimer's disease, Neurobiol Aging 18 (1997), 415-421.

[436] S. Webster, S. O'Barr and J. Rogers, Enhanced aggregation and beta structure of amyloid beta peptide after coincubation with C1q, J. Neurosci. Res. 39 (1994), 448-456.

[437] S. Webster and J. Rogers, Relative efficacies of amyloid beta peptide $(\mathrm{A} \beta$ ) binding proteins in A beta aggregation, $\mathrm{J}$. Neurosci. Res. 46 (1996), 58-66.

[438] S.D. Webster, A.J. Yang, L. Margol, W. Garzon-Rodriguez, C.G. Glabe and A.J. Tenner, Complement component Clq modulates the phagocytosis of Abeta by microglia, Exp Neurol 161 (2000), 127-138.

[439] J. Wegiel and H.M. Wisniewski, Astrocyte pathology in Alzheimer's Disease, in: Astrocytes in brain aging and neurodegeneration, H.M. Schipper, ed., R.G. Landes Company, Austin, TX, 1998, pp. 91-109.

[440] T. Wetterling and K.F. Tegtmeyer, Serum alpha 1-antitrypsin and alpha 2-macroglobulin in Alzheimer's and Binswanger's disease, Clin. Investig. 72 (1994), 196-199.

[441] K. Whaley and W. Schwaeble, Complement and complement deficiencies, Semin. Liver Dis. 17 (1997), 297-310.

[442] S.E. Williams, M.Z. Kounnas, K.M. Argraves, W.S. Argraves and D.K. Strickland, The alpha 2-macroglobulin receptor/low density lipoprotein receptor- related protein and the receptor-associated protein. An overview, Ann. N. Y. Acad. Sci. 737 (1994), 1-13.

[443] H.M. Wisniewski and B.R. Bloom, Primary demyelination as a nonspecific consequence of a cell-mediated immune reaction, J. Exp Med. 141 (1975), 346-359.

[444] H.M. Wisniewski, R.S. Sinatra and K. Iqbal et al., Neurofibrillary and synaptic pathology in the aged brain, in: Aging and Cell Structure, A.E. Johnson, ed., Plenum Publishing, New York, 1981, pp. 105-142.

[445] H.M. Wisniewski, J. Wegiel, K.C. Wang, M. Kujawa and B. Lach, Ultrastructural studies of the cells forming amyloid fibers in classical plaques, Can. J. Neurol. Sci. 16 (1989), 535-542.

[446] T. Wisniewski, M. Lalowski and M. Baumann et al., HBGAM is a cytokine present in Alzheimer's and Down's syndrome lesions, Neuroreport. 7 (1996), 667-671.

[447] B.B. Wolf, M.B. Lopes, S.R. VandenBerg and S.L. Gonias, Characterization and immunohistochemical localization of alpha 2- macroglobulin receptor (low-density lipopro- 
tein receptor-related protein) in human brain, Am. J. Pathol. 141 (1992), 37-42.

[448] P.T. Wong, P.L. McGeer and E.G. McGeer, Decreased prostaglandin synthesis in postmortem cerebral cortex from patients with Alzheimer's disease, Neurochem. Int. 21 (1992), 197-202.

[449] J.A. Wood, P.L. Wood and R. Ryan et al., Cytokine indices in Alzheimer's temporal cortex: no changes in mature IL-1 beta or IL-1RA but increases in the associated acute phase proteins IL-6, alpha 2-macroglobulin and C-reactive protein, Brain Res. 629 (1993), 245-252.

[450] J.G. Wood and P. Zinsmeister, Tyrosine phosphorylation systems in Alzheimer's disease pathology, Neurosci. Lett. 121 (1991), 12-16.

[451] M. Xia, S. Qin, M. McNamara, C. Mackay and B.T. Hyman, Interleukin-8 receptor B immunoreactivity in brain and neuritic plaques of Alzheimer's disease, Am. J. Pathol. 150 (1997), 1267-1274.

[452] M.Q. Xia, B.J. Bacskai, R.B. Knowles, S.X. Qin and B.T. Hyman, Expression of the chemokine receptor CXCR3 on neurons and the elevated expression of its ligand IP-10 in reactive astrocytes: in vitro ERK1/2 activation and role in Alzheimer's disease, J. Neuroimmunol. 108(2000), 227-235.

[453] M.Q. Xia and B.T. Hyman, Chemokines/chemokine receptors in the central nervous system and Alzheimer's disease, J. Neurovirol. 5 (1999), 32-41.

[454] M.Q. Xia, S.X. Qin, L.J. Wu, C.R. Mackay and B.T. Hyman, Immunohistochemical study of the beta-chemokine receptors CCR3 and CCR5 and their ligands in normal and Alzheimer's disease brains, Am. J. Pathol. 153 (1998), 31-37.

[455] K. Yamada, K. Kono and H. Umegaki et al., Decreased interleukin-6 level in the cerebrospinal fluid of patients with Alzheimer-type dementia, Neurosci. Lett. 186 (1995), 219 221.

[456] T. Yamada, H. Akiyama and P.L. McGeer, Complementactivated oligodendroglia: a new pathogenic entity identified by immunostaining with antibodies to human complement proteins C3d and C4d, Neurosci. Lett. 112 (1990), 161-166.

[457] T. Yamada, M.A. Horisberger, N. Kawaguchi, I. Moroo and T. Toyoda, Immunohistochemistry using antibodies to alphainterferon and its induced protein, MxA, in Alzheimer's and Parkinson's disease brain tissues, Neurosci. Lett. 181 (1994), 61-64.

[458] T. Yamada, Y. Yoshiyama and N. Kawaguchi, Expression of activating transcription factor-2 (ATF-2), one of the cyclic AMP response element (CRE) binding proteins, in Alzheimer disease and non-neurological brain tissues, Brain Res 749 (1997), 329-334.

[459] K. Yamagata, K.I. Andreasson, W.E. Kaufmann, C.A. Barnes and P.F. Worley, Expression of a mitogen-inducible cyclooxygenase in brain neurons: regulation by synaptic activity and glucocorticoids, Neuron 11 (1993), 371-386.

[460] H. Yamaguchi, M. Morimatsu, S. Hirai and K. Takahashi, Alzheimer's neurofibrillary tangles are penetrated by astroglial processes and appear eosinophilic in their final stages, Acta Neuropathol. (Berl.) 72 (1987), 214-217.

[461] M. Yamamoto-Sasaki, H. Ozawa, T. Saito, M. Rosler and P. Riederer, Impaired phosphorylation of cyclic AMP response element binding protein in the hippocampus of dementia of the Alzheimer type, Brain Res 824 (1999), 300-303.

[462] K. Yamamoto, T. Arakawa, N. Ueda and S. Yamamoto, Transcriptional roles of nuclear factor kappa B and nuclear factorinterleukin-6 in the tumor necrosis factor alpha-dependent induction of cyclooxygenase-2 in MC3T3-E1 cells, J. Biol. Chem. 270 (1995), 31315-31320.

[463] K. Yamamoto, T. Miyoshi and T. Yae et al., The survival of rat cerebral cortical neurons in the presence of trophic APP peptides, J. Neurobiol. 25 (1994), 585-594.

[464] S.D. Yan, X. Chen and J. Fu et al., RAGE and amyloid-beta peptide neurotoxicity in Alzheimer's disease, Nature 382 (1996), 685-691.

[465] S.D. Yan, S.F. Yan and X. Chen et al., Non-enzymatically glycated tau in Alzheimer's disease induces neuronal oxidant stress resulting in cytokine gene expression and release of amyloid beta-peptide, Nat. Med. 1 (1995), 693-699.

[466] S.D. Yan, H. Zhu and J. Fu et al., Amyloid-beta peptidereceptor for advanced glycation endproduct interaction elicits neuronal expression of macrophage-colony stimulating factor: a proinflammatory pathway in Alzheimer disease, Proc. Natl. Acad. Sci. USA 94 (1997), 5296-5301.

[467] L.B. Yang, R. Li, S. Meri, J. Rogers and Y. Shen, Deficiency of complement defense protein CD59 may contribute to neurodegeneration in Alzheimer's disease, J. Neurosci. 20 (2000), in press.

[468] K. Yasojima, E.G. McGeer and P.L. McGeer, Complement regulators $\mathrm{C} 1$ inhibitor and CD59 do not significantly inhibit complement activation in Alzheimer disease, Brain Res $\mathbf{8 3 3}$ (1999), 297-301.

[469] K. Yasojima, C. Schwab, E.G. McGeer and P.L. McGeer, Distribution of cyclooxygenase- 1 and cyclooxygenase- $2 \mathrm{mR}$ NAs and proteins in human brain and peripheral organs, Brain Res 830 (1999), 226-236.

[470] K. Yasojima, C. Schwab, E.G. McGeer and P.L. McGeer, Upregulated production and activation of the complement system in Alzheimer's disease brain, Am. J. Pathol. 154 (1999), 927-936.

[471] O. Yasuhara, A. Matsuo and K. Terai et al., Expression of interleukin-1 receptor antagonist protein in post-mortem human brain tissues of Alzheimer's disease and control cases, Acta Neuropathol (Berl.) 93 (1997), 414-420.

[472] O. Yasuhara, H. Muramatsu, S.U. Kim, T. Muramatsu, H. Maruta and P.L. McGeer, Midkine, a novel neurotrophic factor, is present in senile plaques of Alzheimer disease, Biochem. Biophys. Res Commun. 192 (1993), 246-251.

[473] O. Yasuhara, D.G. Walker and P.L. McGeer, Hageman factor and its binding sites are present in senile plaques of Alzheimer's disease, Brain Res. 654 (1994), 234-240.

[474] A.V. Yermakova, J. Rollins, L.M. Callahan, J. Rogers and M.K. O'Banion, Cyclooxygenase-1 in human Alzheimer and control brain: quantitative analysis of expression by microglia and CA3 hippocampal neurons, J. Neuropathol Exp Neurol 58 (1999), 1135-1146.

[475] D.T. Yew, W.P. Li, S.E. Webb, H.W. Lai and L. Zhang, Neurotransmitters, peptides, and neural cell adhesion molecules in the cortices of normal elderly humans and Alzheimer patients: a comparison, Exp Gerontol. 34 (1999), 117-133.

[476] C. Zarow, K.E. Schlueter and Q. Zhang, Interleukin-6 mRNA is elevated in Alzheimer Disease Brain, Soc. Neurosci. Abstr. 22 (1996), 214.

[477] S.S. Zhan, R. Veerhuis, W. Kamphorst and P. Eikelenboom, Distribution of beta amyloid associated proteins in plaques in Alzheimer's disease and in the non-demented elderly, $\mathrm{Neu}$ rodegeneration 4 (1995), 291-297.

[478] S.G. Zhu, J.G. Sheng and R.A. Jones et al., Increased interleukin-1beta converting enzyme expression and activity in Alzheimer disease, J. Neuropathol Exp Neurol 58 (1999), 582-587. 
Table 1

Inflammatory markers in $\mathrm{AD}$

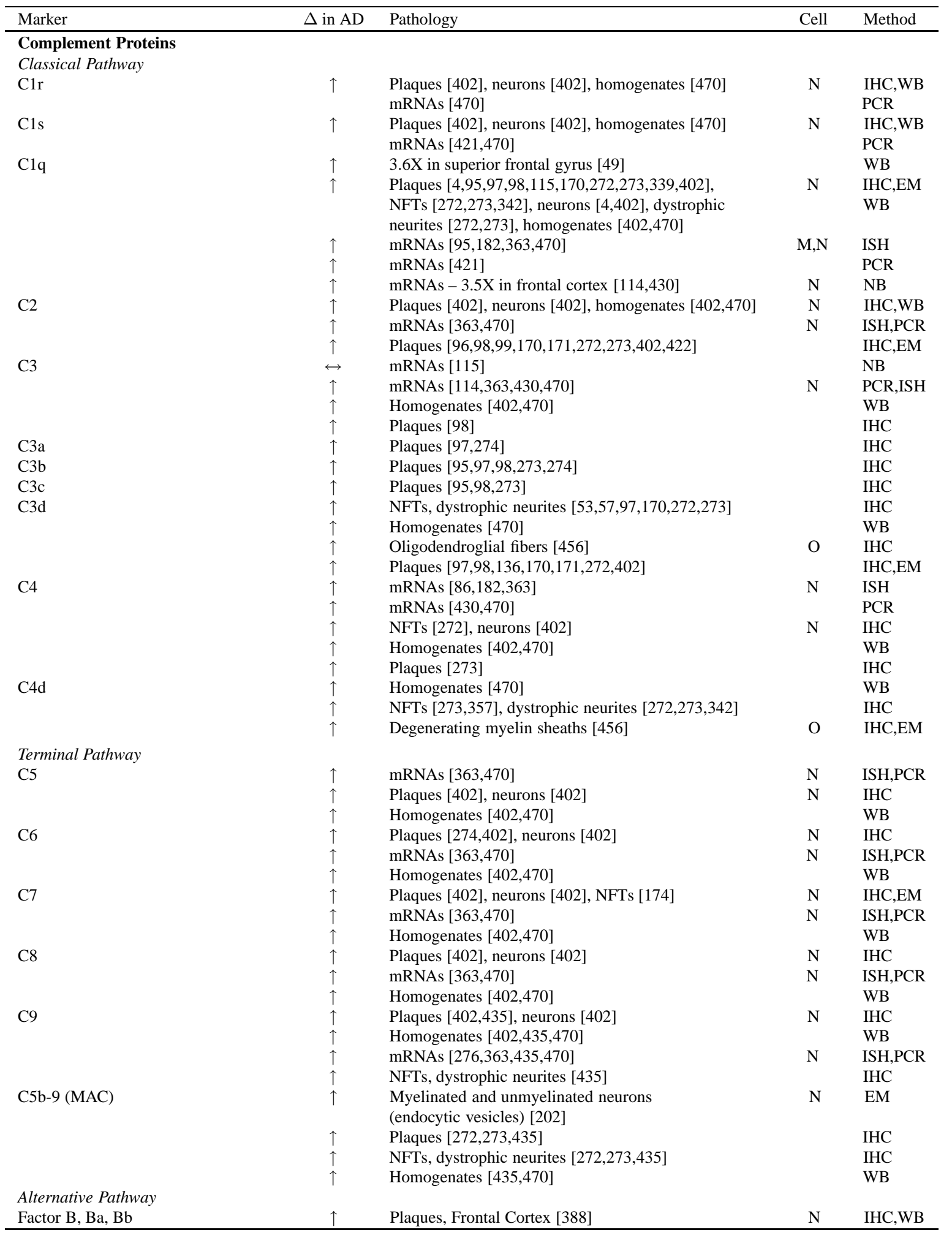


Table 1, continued

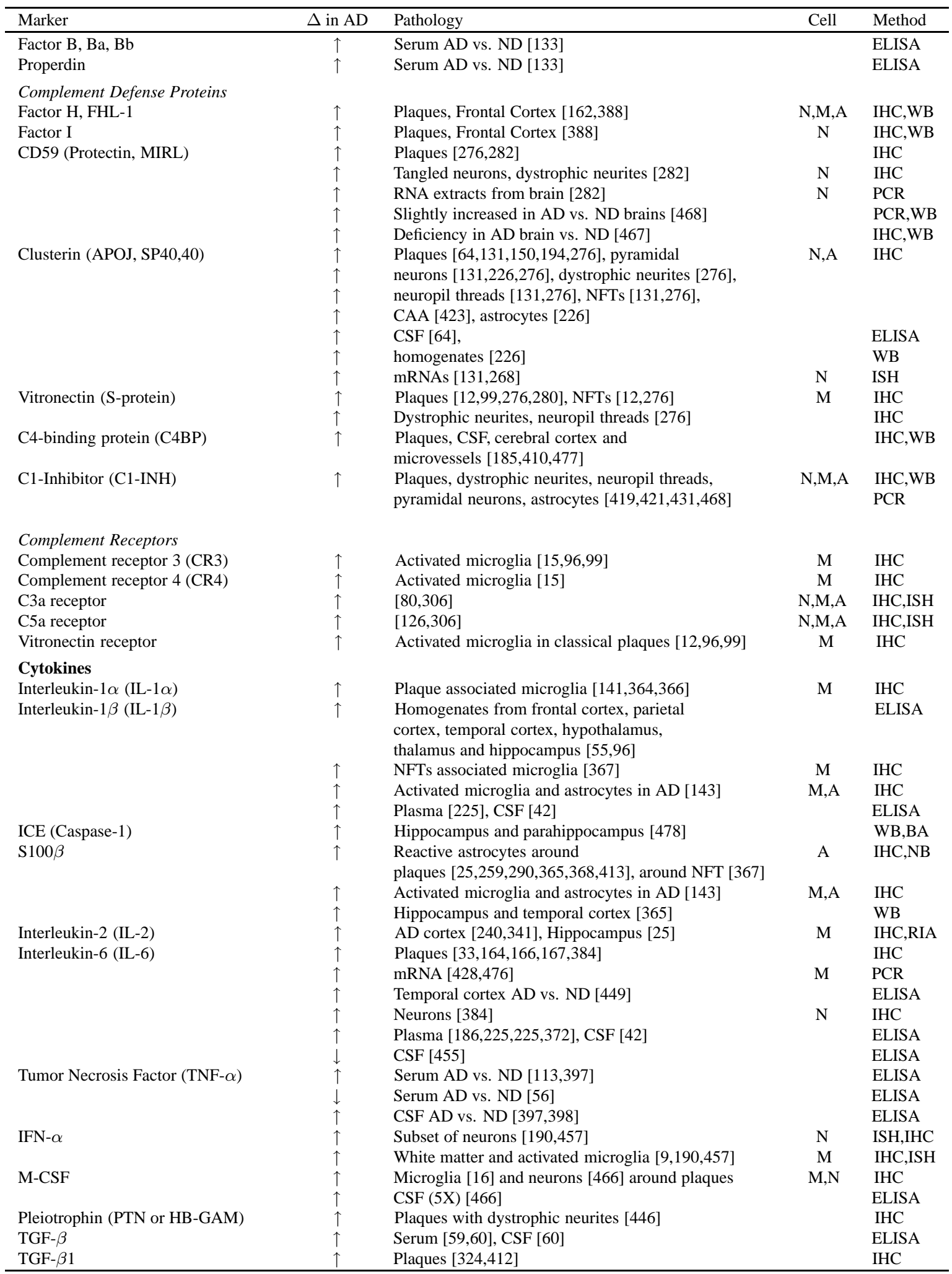


Table 1, continued

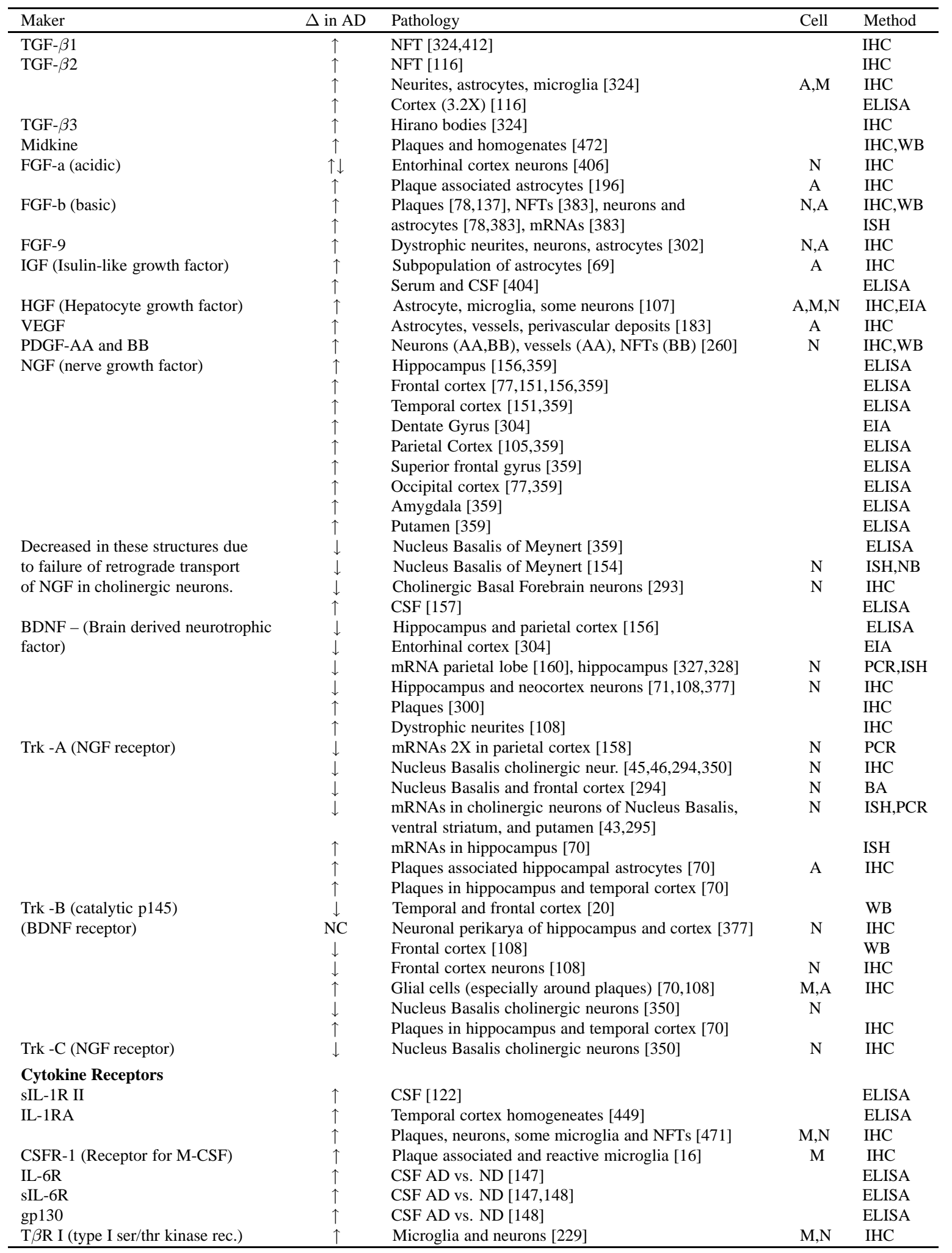


Table 1, continued

\begin{tabular}{|c|c|c|c|c|}
\hline Marker & $\Delta$ in $\mathrm{AD}$ & Pathology & Cell & Method \\
\hline T $\beta$ R II (type II ser/thr kinase rec.) & $\uparrow$ & Microglia and neurons [229] & $\mathrm{M}, \mathrm{N}$ & IHC \\
\hline \multirow[t]{3}{*}{ FAS (CD95) } & $\uparrow$ & Frontal and temporal lobe homogenates [82] & & WB \\
\hline & $\uparrow$ & Neurons and dystrophic neurites $[82,308]$ & $\mathrm{N}$ & $\mathrm{IHC}$ \\
\hline & $\uparrow$ & Plaques and associated astrocytes [308] & A & $\mathrm{IHC}$ \\
\hline EGFR & $\uparrow$ & Neuritic plaques [38], endothelial cells [390] & $\mathrm{E}$ & IHC,EM \\
\hline FGFR-1 & $\uparrow$ & Plaque associated astrocytes, neurons, mRNAs [395] & $\mathrm{A}, \mathrm{N}$ & IHC,ISH \\
\hline FGFR-3 & $\uparrow$ & Plaque associated astrocytes [109] & A & $\mathrm{IHC}$ \\
\hline \multicolumn{5}{|l|}{ Chemokines and Receptors } \\
\hline Chemokines & & In AD : Reviewed in [453] & & \\
\hline IP-10 & $\uparrow$ & Astrocytes (especially around plaques) [452] & A & $\mathrm{IHC}$ \\
\hline MIP- $1 \alpha(\mathrm{CC} \beta)$ & $\uparrow$ & Neurons, microglia (weakly) [454] & $\mathrm{N}, \mathrm{M}$ & $\mathrm{IHC}$ \\
\hline MIP-1 $\beta(\mathrm{CC} \beta)$ & $\uparrow$ & Astrocytes (especially around plaques) $[452,454]$ & A & $\mathrm{IHC}$ \\
\hline $\mathrm{MCP}-1(\mathrm{CC} \beta)$ & $\uparrow$ & Plaques, microglia [172] & M & $\mathrm{IHC}$ \\
\hline Chemokine Receptors & & In AD : Reviewed in [453] & & \\
\hline CXCR3 (IP-10 receptor) & $\uparrow$ & Neurons [452] & $\mathrm{N}$ & $\mathrm{IHC}$ \\
\hline \multirow{2}{*}{ CXCR2 (IL-8RB) } & $\uparrow$ & Plaques $[163,451]$ & & $\mathrm{IHC}$ \\
\hline & $\uparrow$ & Neurons and dystrophic neurites [451] & $\mathrm{N}$ & $\mathrm{IHC}$ \\
\hline \multirow[t]{2}{*}{ CCR3 } & $\uparrow$ & Microglia (especially in plaques) [454] & M & $\mathrm{IHC}$ \\
\hline & $\uparrow$ & Microglia (especially in plaques) [454] & M & $\mathrm{IHC}$ \\
\hline \multicolumn{5}{|l|}{ Cell Surface Markers } \\
\hline MHC I & $\uparrow$ & Endothelial cells $[273,409]$, microglia $[281,409]$ & E,M & IHC \\
\hline \multicolumn{5}{|c|}{ e } \\
\hline \multirow[t]{2}{*}{ HLA-DR } & $\uparrow$ & $\begin{array}{l}\text { Activated microglia (concentrated in plaques) } \\
{[15,96,121,173,240,263, ?, 281,341,409]}\end{array}$ & M & $\mathrm{IHC}$ \\
\hline & $\uparrow$ & [389] & M & IHC,EM \\
\hline HLA-DP & $\uparrow$ & [240] & M & $\mathrm{IHC}$ \\
\hline HLA-DQ & $\uparrow$ & [240] & M & IHC \\
\hline LCA & $\uparrow$ & Activated microglia [15] & M & $\mathrm{IHC}$ \\
\hline \multicolumn{5}{|l|}{$\begin{array}{l}\text { Cyclooxygenase }(\mathrm{COX}) \text { and } \\
\text { Eicosanoids }\end{array}$} \\
\hline Cyclooxygenase & & COX in AD: Reviewed in [311] & & \\
\hline PLA2 (Phospholipase A2) & $\downarrow$ & Cerebral cortex (multiple areas) $[127,128,345]$ & & BA \\
\hline cPLA2 (cytosolic PLA2) & $\uparrow$ & Cerebral cortex protoplasmic astrocytes [382] & A & $\mathrm{IHC}$ \\
\hline \multirow[t]{4}{*}{ COX-1 } & $\uparrow$ & Cortical homogenates $[198,469]$ & & WB \\
\hline & $\uparrow$ & Hippocampus and neocortex neurons $[469,474]$ & $\mathrm{N}$ & IHC,ISH \\
\hline & $\uparrow$ & Microglia (especially in plaques) [474] & M & $\mathrm{IHC}$ \\
\hline & $\uparrow$ & mRNAs $[244,469]$ & & PCR,NB \\
\hline \multirow[t]{3}{*}{$\mathrm{COX}-2$} & $\uparrow$ & Frontal [322], hippocampal [155], and temporal & & IHC,WB \\
\hline & $\uparrow$ & cortex [198], neurons [314,469] and NFTs [314] & $\mathrm{N}$ & IHC,WB \\
\hline & $\uparrow$ & mRNAs $[244,245,469]$ & & PCR,NB \\
\hline \multirow{2}{*}{\multicolumn{5}{|c|}{ Eicosanoids }} \\
\hline & & & & \\
\hline Prostaglandin D2 (PGD2) & $\downarrow$ & Cortex AD vs. ND $[175,448]$ & & BA \\
\hline \multirow{2}{*}{ Prostaglandin $\mathrm{E}^{2}\left(\mathrm{PGE}^{2}\right)$} & $\downarrow$ & Frontal cortex AD vs. ND [448] & & BA \\
\hline & $\uparrow$ & $5 \mathrm{X}$ in CSF [287] & & GC/MS \\
\hline Prostaglandin F1( (PGF1() & $\downarrow$ & $4 \mathrm{X}$ in CSF [287] & & GC/MS \\
\hline Prostaglandin F2( (PGF2() & $\downarrow$ & Frontal cortex AD vs. ND [448] & & BA \\
\hline Isoprostanes & $\uparrow$ & CSF [286,287,333], cortex [310,333] & & GC/MS \\
\hline Thromboxane B2 (TXB2) & $\downarrow$ & Cortex AD vs. ND $[175,448]$ & & $\mathrm{BA}$ \\
\hline \multicolumn{5}{|l|}{$\begin{array}{l}\text { Coagulation and Fibrinolysis } \\
\text { Systems }\end{array}$} \\
\hline Prothrombin & $\uparrow$ & In areas of vascular damage [37] & & $\mathrm{IHC}$ \\
\hline Thrombin & $\uparrow$ & Plaques, Tangles $[7,8,11,277]$ & & $\mathrm{IHC}$ \\
\hline Antithrombin III & $\uparrow$ & $\begin{array}{l}\text { Plaques, tangles, paired helical filaments, } \\
\text { dystrophic neurites, some astrocytes, mRNAs [184] }\end{array}$ & A & $\begin{array}{l}\text { IHC,WB } \\
\text { EM,PCR }\end{array}$ \\
\hline Tissue factor (thromboplastin) & $\uparrow$ & Plaques [269] & & $\mathrm{IHC}$ \\
\hline Tissue factor pathway inhibitor- 1 & $\uparrow$ & Plaques and microglia [159] & M & $\mathrm{IHC}, \mathrm{WB}$ \\
\hline Hageman factor & $\uparrow$ & Plaques, mRNAs [473] & & PCR,WB \\
\hline TPA & $\uparrow$ & Plaques [335] & & $\mathrm{IHC}$ \\
\hline
\end{tabular}


Table 1 , continued

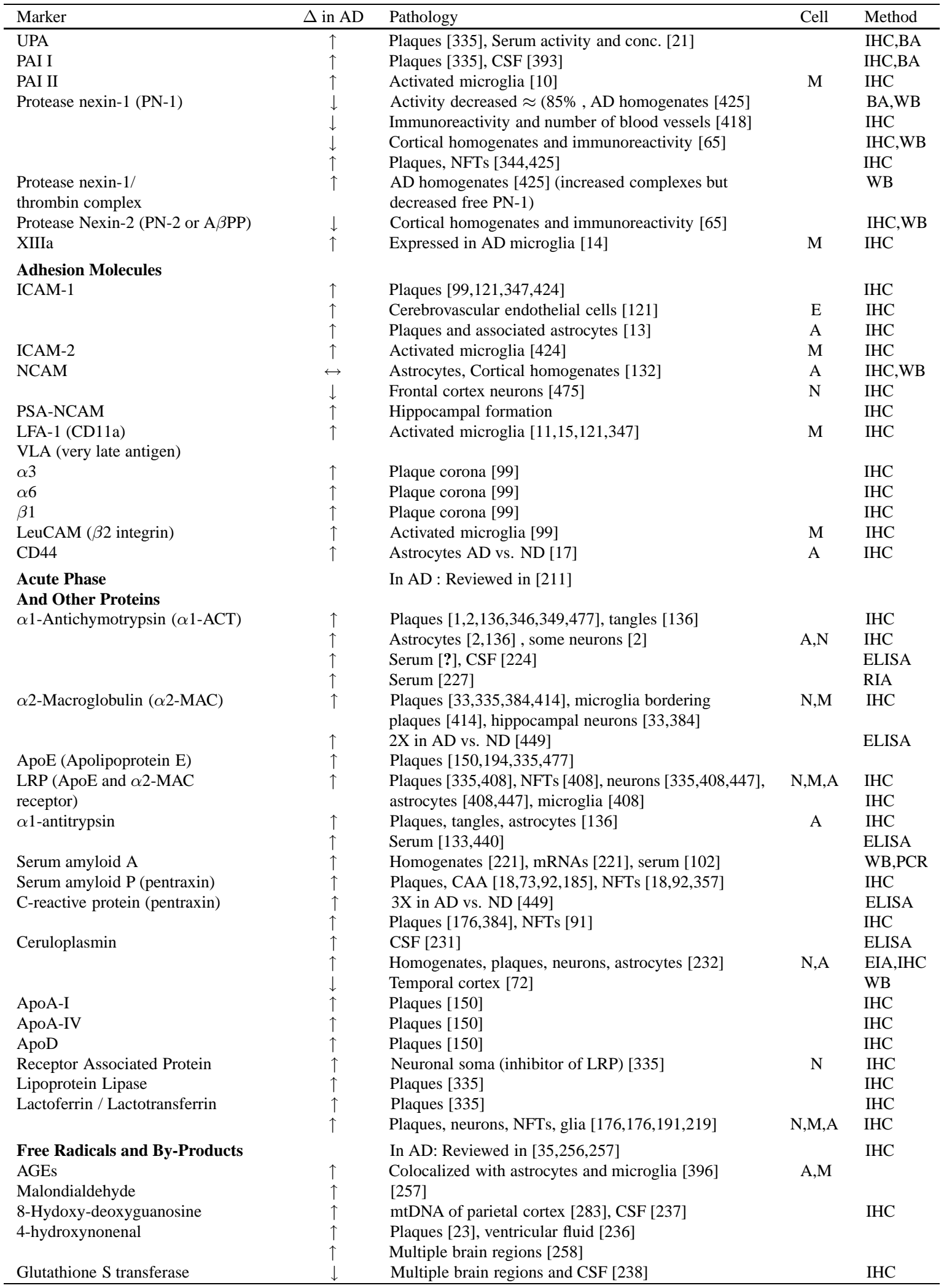

